\title{
Exploring the emotional antecedents and outcomes of technology acceptance
}

\begin{abstract}
The Internet has become an essential platform for communication and a vital approach to accessing information in people's daily life. Exploring the antecedents and outcomes of Internet acceptance from the psychological and emotional perspectives remains an area that warrants further investigation. This article constructs and empirically tests a comprehensive research framework, namely the emotional-TAM (E-TAM). This model is tested with data collected from 615 Internet users in the United States. The findings indicate that Internet acceptance is related to social inclusion and the fulfilment of three types of psychological needs derived from Self-Determination Theory. The continuance intention of using the Internet significantly relates to the users' degree of well-being, perceived value, and four categories of emotions. A number of significant moderating effects were also found.
\end{abstract}

Keywords: technology acceptance, emotions, social inclusion, psychological needs, wellbeing, Big-5 personality traits 


\section{Exploring the emotional antecedents and outcomes of technology acceptance}

\section{Introduction}

Over the years, there has been an increasing interest in exploring the potential emotional influence of pervasive technologies, such as the Internet. For instance, the Internet has been shown to work as an intervention technique which contributes to health-related behaviour change, e.g. in cognitive behaviour therapy toward anxiety disorders (Andersson, 2009; Webb et al., 2010). On the other hand, pre-existing psychopathology and social isolation can develop and reinforce symptoms of pathological Internet use (Davis, 2001; LaRose, 2010; Munno et al., 2017). In turn, this can lead to negative effects, such as social disinhibition, depression, lower self-esteem, and greater loneliness (Niemz, Griffiths, \& Banyard, 2005; Tokunaga, 2017; Kim, LaRose, \& Peng, 2009). Studies from a psychological perspective have largely been focused on the impact of excessive Internet use, especially its negative causes and effects (e.g. problematic Internet use, Internet addiction, compulsive Internet use). However, there has been little discussion about the wider emotional consequences that the Internet can bring to the public. As such this study's first objective is to make a contribution by exploring the emotional antecedents and outcomes of using the Internet.

By tackling this objective, this paper aims to make a second significant contribution related to technology acceptance. Over the years, the Technology Acceptance Model (TAM) has facilitated understanding of technology acceptance and has made possible extensions and elaborations for the contextualisation of information technology (IT) studies (Lee, Kozar, \& Larsen, 2003). At the same time, though, excessive focus on replication and the subtle adaptation of popular models such as TAM could restrict the progress of information system (IS) research (Venkatesh, Davis, \& Morris, 2007; Venkatesh, L. Thong, \& Xu, 2012a). Integrating individual characteristics, rather than over-emphasising system and design characteristics, may offer a way to enhance IS and IT studies (Benbasat \& Barki, 2007; Venkatesh, 2000). To this end, a number of studies have incorporated psychological factors, such as cognitive absorption (Mohd Suki, Ramayah, \& Mohd Suki, 2008), flow (Hausman \& Siekpe, 2009), psychological needs and self-determination (Partala \& Saari, 2015; Partala, 2011), and emotions (Beaudry \& Pinsonneault, 2010), etc. Still, there is much more scope for considering psychological factors as antecedents and outcomes of acceptance. Given that psychological states and individual differences are gaining importance in technology acceptance studies, this article extends TAM by incorporating emotional constructs, i.e. social inclusion, basic psychological needs, well-being, perceived value, and emotions. A number of moderating effects have also highlighted the changes in the hypothesised causal relationships when personal attributes are taken into consideration.

\section{Literature review and hypothesis development}

\subsection{Technology acceptance}

Over the years TAM has been one of the key theories aiming to explain technology acceptance. Compared with other technology acceptance theories, TAM is considered appropriate as a baseline model for this study for three reasons. First, TAM is parsimonious, making it possible to extend it in a number of different ways, without resulting in a very complicated model (Venkatesh et al., 2003; Taylor \& Todd, 1995; Bagozzi, 2007). In addition, the "beliefs and attitudes - intention - behaviour" causal chain underlies popular theories and models such as the Theory of Planned Behaviour (TPB) or the Unified Theory of Acceptance and Use of Technology (UTAUT) (Bagozzi, Davis, \& Warshaw, 1992; Davis, Bagozzi, \& Warshaw, 1989; Venkatesh et al., 2003; Taylor \& Todd, 1995). As such it offers sufficient theoretical representativeness. Finally, TAM is robust, reliable, operationally efficient, and 
offers sufficient explanatory power (Mathieson, 1991; Venkatesh et al., 2003; Davis, 1989). On the other hand, TAM has been criticised with respect to the one-dimensional, oversimplifying definition of acceptance, and to the intention-behaviour linkage, which has been insufficiently validated by empirical research or has resulted in varying findings, due to methodological issues (such as common methods bias) or moderator variables that impact on the entire acceptance model (Nistor, 2014).

Based on the above, TAM was adopted as a starting point, and a number of extensions were added, as Figure 1 illustrates. The outline model is operationalised below by testing the hypotheses that are presented in the sections following.

\section{Figure 1 Conceptual framework}

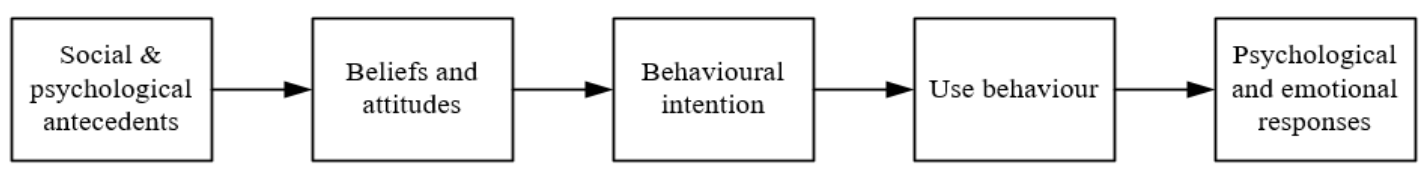

The first version of TAM includes five main constructs, namely, perceived usefulness (PU), perceived ease of use (PEOU), attitude toward using (Attitude), behavioural intention to use (BI), and actual system use (USE) (Davis et al., 1989). Davis et al. (1989) showed that PU and PEOU have direct effects on BI instead of being mediated by attitude. The authors suggested omitting attitude to explain intention more concisely (Davis et al., 1989; Venkatesh et al., 2003). PU and PEOU are grounded on behavioural psychology and the observation of technology adoption (Davis et al., 1989). They are the two most influential determinants that represent human beliefs and represent the foundation of technology acceptance theories (Davis, 1989; Venkatesh \& Davis, 2000; Davis et al., 1989). PEOU is the degree to which a person believes that using the Internet would be free of effort (Davis et al., 1989; Davis, 1989). PU refers to the degree to which a person believes that using the Internet would enhance performance in completing particular tasks (Davis et al., 1989; Davis, 1989). The relationships between PU, PEOU, and Intention have been retained in most TAM-based empirical studies (Lee et al., 2003). Additionally, a meta-analysis by Lee et al. (2003) showed that the majority of the studies support the idea that PEOU is related to PU, and both PU and PEOU relate to Intention or USE. As our study's samples involve existing users, we have focused on the intentions to continue using the internet (continuance intention (CI)).

This leads to the first set of hypotheses:

H1: An individual's (a) perceived ease of use, and (b) perceived usefulness of using the Internet is positively related to the intention to continue using it, while (c) perceived ease of use positively relates to the perceived usefulness of the Internet.

\subsection{Social inclusion and information and communication technologies}

Various definitions of social inclusion have been introduced over the years that offer different vantage points into this multi-dimensional phenomenon (e.g. Secker et al., 2009; Sayce, 2001; Huxley et al., 2012; The Charity Commission, 2001). Social inclusion is defined as " $a$ virtuous circle of improved rights of access to the social and economic world, new opportunities, recovery of status and meaning, and reduced impact of disability" (Sayce, 2001). Although social inclusion is based on the concept of social exclusion, social inclusion cannot be simply viewed as "non-exclusion", but rather as creating opportunities proactively and having freedom in making choices (Andrade \& Doolin, 2016; Selwyn, 2002). In the context of this study, we elaborate on the previous definition by also considering the work by Richardson \& Le Grand (2002) and by Burchardt et al. (1999). We define an individual as socially included if he or she is geographically resident in a society and proactively participates in the activities / services of citizens in that society. Examples of such activities could be access to healthcare or the ability to obtain credit (Burchardt et al., 1999). Hence, 
social inclusion relates to the emotional and health benefits generated by access to social capital, social acceptance and social activity, as well as positive actions taken by an individual to deal with social exclusion, then enabling people to fully participate in the society (Andrade \& Doolin, 2016; Sayce, 2001; Secker et al., 2009; The Charity Commission, 2001). Being included in a group is a fundamental need and fulfilment of this need enhances one's wellbeing (Deci \& Ryan, 2000; Tay \& Diener, 2011; Ryan \& Deci, 2000c). A low degree of social inclusion may limit an individual's access to social support and public services (Kennan et al., 2011). When it comes to the relationship between social inclusion and information and communication technologies (ICTs), studies have shown that the diffusion of innovative technology and implementation of ICTs closely relate to people's perceived social inclusion, either positively or negatively (Tapia, Kvasny, \& Ortiz, 2011; Broadbent \& Papadopoulos, 2013; Andrade \& Doolin, 2016; Hill, Betts, \& Gardner, 2015). Social isolation, depression, and social anxiety have been found to relate to Internet addiction (Casale \& Fioravanti, 2015; Davis, 2001).

Not surprisingly, social inclusion / exclusion closely relates to digital inclusion / exclusion, with high digital inclusion being a catalyst for social inclusion (Hill et al., 2015; Selwyn, 2002; Tapia et al., 2011). With the proliferation of ICTs, digital inclusion has become an increasingly important issue as it describes how ICTs serve society and promote social inclusion (Tapia et al., 2011; Hill et al., 2015). Diffusion of new forms of technological breakthrough could potentially exacerbate existing social exclusion or even create new ways through which digital exclusion can be manifested (Andrade \& Doolin, 2016). On the other hand, it can also bring many advantages. First of all, social inclusion motivates people to use connecting technologies such as mobile phones, social networking sites, and e-learning systems (Choi \& Chung, 2013; Park, 2010; Park et al., 2013; Smith \& Sivo, 2012). Empirical results suggest that social inclusion has positive effects on one's PU, PEOU, and CI of using mobile phones (Park et al., 2013). Social capital is a key element of social inclusion, which is generated through an individuals' social activities and interactions, and offers benefits for their social participation (Choi \& Chung, 2013; Secker et al., 2009). Perceived social capital positively and significantly relates to perceived usefulness and ease-of-use of SNS among graduate students (Choi \& Chung, 2013). Social presence and sociability facilitate users' degree of social inclusion as well, which has been found to positively correlate with PU, PEOU, and CI in using e-learning systems (Smith \& Sivo, 2012). Moreover, the beneficial impact of social inclusion is also reflected in enhancing the well-being of citizens (especially those ICT-engaged individuals) via technology use. For instance, socially excluded people tend to shop online via computer or cell phone rather than in-store (Dennis et al., 2016). Such preferences can potentially mitigate the negative effects of social exclusion on well-being and the happiness of individuals with mobility difficulties. It is worth noting that ICTs do not increase social inclusion automatically. They promote participation in social activities and communities, and in turn can help transform social inclusion into well-being (Andrade \& Doolin, 2016). On one hand, ICT usage facilitates participation in communities with valued relationships and collective social capital, which ultimately increases social inclusion (Broadbent \& Papadopoulos, 2013; Hill et al., 2015). On the other hand, ICTs have been found to be a resource of five valuable capabilities that contribute to social involvement in the case of newly resettled refugees (Andrade \& Doolin, 2016). These individuals' well-being in the new communities increased with the aid of these capabilities offered by ICTs: i.e. participating in an information society; communicating effectively; understanding a new society; being socially connected; and expressing a cultural identity (Andrade \& Doolin, 2016).

Based on the previous empirical evidence it is proposed that:

H2: Social inclusion positively relates to the users' (a) perceived ease of use of, (b) perceived usefulness of, and (c) continuance intention of using the Internet. 


\subsection{Self-determination theory, basic psychological needs, and technology acceptance}

According to Self-Determination Theory (SDT), when faced with new skills and ideas, people have innate needs to feel effective, agentic and being connected, which derive from the three basic psychological needs for competence, autonomy, and relatedness (Ryan \& Deci, 2000c; Ryan \& Deci, 2000b). The need for competence refers to the human intention to effectively interact with the environment in order to experience the feeling of competence when performing an activity (Deci \& Ryan, 2000; Lee, Lee, \& Hwang, 2015; Roca \& Gagné, 2008; Van den Broeck et al., 2010). The need for autonomy is defined as an individual's innate desire to experience psychological freedom and the sense of choice in activity engagement (Deci \& Ryan, 2000; Van den Broeck et al., 2010). The need for relatedness is a feeling of being connected to, being loved and supported by, others, and belonging to social communities (Lee et al., 2015; Roca \& Gagné, 2008; Van den Broeck et al., 2010).

These three psychological needs are the basis for maintaining an individual's intrinsic motivation and self-determining extrinsic motivation (Ryan \& Deci, 2000b). Specifically, interpersonal activities can catalyse people's need for competence and fulfilling this need enhances their intrinsic motivation (Gagné \& Deci, 2005; Ryan \& Deci, 2000b). Intrinsic motivations could be diminished by external factors such as rewards, threats, deadlines, and competition pressure, which hinder the autonomy experienced by the individuals (Gagné \& Deci, 2005; Ryan \& Deci, 2000b). The environmental and social contextual conditions that support or control the needs for autonomy and competence could facilitate or undermine intrinsic motivation and social functioning (Ryan \& Deci, 2000c; Ryan \& Deci, 2000b). Satisfying the need for relatedness is the main motivation driving people to perform activities which, per se, are less enjoyable or not of interest, but valued by people connected to them (Roca \& Gagné, 2008).

Studies based on SDT have reported close relationships between Internet use, needs satisfaction, and psychological states. Need fulfilment can indirectly lead to excessive Internet use, which is fully mediated by psychological distress (Wong, Yuen, \& Li, 2014). Psychological distress, such as social anxiety, has direct influences on excessive Internet use as well (Casale \& Fioravanti, 2015). For males, this can be partially mediated by the satisfaction of the need for self-presentation, which can be met through social networking service use (Casale \& Fioravanti, 2015). In addition, the basic psychological need satisfaction perceived online and in daily life both significantly predicts Internet use behaviour and the emotional effect among elementary school children (Shen, Liu, \& Wang, 2013). Participants who fulfilled their psychological needs online tend to spend more time on and more frequently use the Internet, and they will also experience more positive outcomes (Shen et al., 2013). In the context of e-learning system use, users can be intrinsically motivated by fulfilling the three psychological needs, which in turn affects their well-being and emotional responses (Gagné \& Deci, 2005; Roca \& Gagné, 2008; Ryan \& Deci, 2000b; Ryan \& Deci, 2000a). The need for autonomy is one of the salient needs that could be satisfied to a significantly larger extent by technology use, especially in successful cases of technology adoption (Partala, 2011; Partala \& Saari, 2015).

Previous work which incorporated the SDT with technology acceptance theories supported a number of relationships between the three psychological needs and technology acceptance constructs. More specifically, although PEOU has been found to be positively affected by the three psychological needs (Nikou \& Economides, 2017; Roca \& Gagné, 2008), their influence on PU and intentions are relatively ambiguous. The majority of the empirical studies suggest that the three needs have significant positive influence on PU and BI, e.g. (Hew \& Kadir, 2016; Huang et al., 2016; Lee et al., 2015). Still, the needs for competence and autonomy were not found to significantly relate to PU in three of the studies (Nikou \& Economides, 2017; Sørebø et al., 2009; Roca \& Gagné, 2008). Notably, these studies were conducted in different contexts, for instance, the e-learning system (Hew \& Kadir, 2016; Roca \& Gagné, 2008; Sørebø et al., 2009), online knowledge sharing system (Lee et al., 
2015), 3D virtual tourism environment (Huang et al., 2016), and mobile-based assessment technology (Nikou \& Economides, 2017). Their models feature additional determinants, such as intrinsic motivation (Sørebø et al., 2009), perceived enjoyment (Lee et al., 2015), perceived playfulness (Roca \& Gagné, 2008), etc.

Based on the findings of prior literature, this study hypothesises that the three dimensions of psychological needs act as motivations for continuing Internet use, as outlined below:

H3: The users' need for competence positively relates to their (a) perceived ease of use of, (b) perceived usefulness of, and (c) continuance intention of using the Internet.

H4: The users' need for autonomy positively relates to their (a) perceived ease of use of, (b) perceived usefulness of, and (c) continuance intention of using the Internet.

H5: The users' need for relatedness positively relates to their (a) perceived ease of use of, (b) perceived usefulness of, and (c) continuance intention of using the Internet.

\subsection{User's well-being, perceived value, and social inclusion}

An individual's degree of well-being can be affected by social inclusion and the satisfaction of basic psychological needs (Andrade \& Doolin, 2016; Dennis et al., 2016; Broadbent \& Papadopoulos, 2013; Ryan \& Deci, 2000c; Deci \& Ryan, 2000; Tay \& Diener, 2011). The positive influence of social inclusion and need fulfilment on well-being can be enhanced by technology use (Roca \& Gagné, 2008; Gagné \& Deci, 2005; Andrade \& Doolin, 2016). Accordingly, this study defines well-being as the degree of need satisfaction and life quality enhancement by using the Internet. Empirical studies have explored the role of wellbeing in technology acceptance. For instance, in studying the mobile money service agents' technology readiness and acceptance, subjective well-being has been found to be a positive outcome of mobile money service use, which was directly affected by PU and PEOU (Rahman et al., 2017). Well-being can act as both a driver and an outcome of social networking service (SNS) use (Munzel, Meyer-Waarden, \& Galan, 2017). Subjective wellbeing can only increase the highly extroverted individuals' time spent on SNS when they are unhappy, which consequently improves their general well-being (Munzel et al., 2017). In addition, well-being can also be measured from the perspective of psychological flourishing (psychological wealth, positive emotions, and life satisfaction) and mental health ("the lack of depressive symptoms") (Partala \& Saari, 2015). Regarding the users' most influential experiences of successful and unsuccessful technology adoptions, psychological flourishing well-being has been found to be largely dependent on the fulfilment of needs and concordance of value (Partala \& Saari, 2015).

H6: Users' continuance intention to use the Internet is positively related to their wellbeing.

Researchers have developed a number of constructs to represent different values affecting technology acceptance and use, such as performance/utilitarian value (e.g. PU and PEOU), hedonic value (e.g. perceived enjoyment and playfulness), social value (e.g. subjective norm and social influence), and monetary value (Davis et al., 1989; Lowry et al., 2013; Venkatesh et al., 2012a). Turel et al. (2007) decomposed users' overall perceived value to a multi-dimensional determinant of short messaging service acceptance. Their study demonstrated that the hedonic and monetary values significantly influence behavioural intention, that performance value was a potential moderator on use intentions and that the social value did not show a significant impact on use intentions (Turel, Serenko, \& Bontis, 2007). On the other hand, perceived performance value, which describes the perceived benefits and profits offered by the IS/IT, has been found to be an antecedent of acceptance of hotel front office systems (Kim, Lee, \& Law, 2008). Wang (2014) investigated utilitarian and monetary aspects of perceived value, which illustrated the user's "overall assessment of the utility" regarding the mobile government system. Results indicated that mobility, security, 
and PU were antecedents of the overall perceived value, while technology satisfaction, trust in technology, trust in the agent, and trust in government were the consequences (Wang, 2014). Users' perceived benefits, i.e. perceived usefulness, perceived enjoyment, and social image, and perceived sacrifice, i.e. perceived risk, were all found to have a positive effect on their overall assessment of the perceived value of media tablet adoption (Yu et al., 2015). Taking into account that this study aims to examine the emotional and psychological factors related to the adoption of a pervasive technological paradigm, i.e. the Internet, the users' perceived value is investigated from a comprehensive perspective. As such, perceived value is defined as the justification of the experience of using the Internet in individuals' daily life, regardless of whether this is for work or for personal purposes (Okada, 2005).

Based on the above it is proposed that:

H7: Users' continuance intention to use the Internet is positively related to their perceived value.

\subsection{Emotional responses to Internet use}

An emotional response is defined as a set of emotional reactions elicited during IT/IS use or by use experiences, such as happiness, anger, anxiety, and excitement. Prior studies provide evidence that users' emotions critically affect beliefs, intentions, and behaviours in technology acceptance and adoption contexts (Beaudry \& Pinsonneault, 2010; Kim \& Lennon, 2013; Chang, Dong, \& Sun, 2014). For instance, positive emotions such as happiness and excitement were found to positively relate to information technology use, either directly or indirectly (Beaudry \& Pinsonneault, 2010). However, negative emotions, e.g. anger and anxiety, also have an indirect positive influence on technology use. These positive and indirect relationships via seeking social support imply that seeking social support may counter the original negative influences of anger and anxiety (Beaudry \& Pinsonneault, 2010). On the other hand, external stimulation, such as adoption and the use of certain technologies, can also trigger users' emotional responses (Chang et al., 2014; Partala \& Saari, 2015; Partala \& Kujala, 2015). For instance, individuals reported significantly different levels of positive and negative emotions in successful and unsuccessful cases of technology adoption (Partala \& Saari, 2015).

This article adopts the Beaudry and Pinsonneault (2010) classification of the emotional responses, specifically toward information technologies. Their framework has been developed by combining two appraisals of technology assessment which determine users' emotional reactions toward a new IT (Beaudry \& Pinsonneault, 2005; Beaudry \& Pinsonneault, 2010). The primary appraisal is whether a user perceives a new technology as constituting an opportunity or a threat, which is in line with the individual's goal achievement (Bagozzi, 1992; Beaudry \& Pinsonneault, 2010). Fundamentally, the goal or outcome of an individual can be either achieved or not, which in turn triggers pleasant or unpleasant feelings toward events in both planned and unplanned cases (Bagozzi, 1992). This primary appraisal determines the users' emotional reactions as positive (they perceive the technology as an opportunity, they achieve the goal) or negative (they perceive the technology as a threat, and do not achieve the goal). Notably, individuals can experience both positive and negative emotions, triggered by the same external stimulation, thus the levels of these two dimensions of emotions can be measured separately (Chang et al., 2014; Partala \& Kujala, 2015; Russell $\&$ Carroll, 1999). The emotions aroused by the adoption of a given IT may vary among individuals depending on their unique psychological evaluations (Beaudry \& Pinsonneault, 2010).

The second appraisal refers to the degree of users' perceived control over the achievement of the expected outcome of accepting a technology (Beaudry \& Pinsonneault, 2010; Lazarus \& Folkman, 1984). This dimension further classified the emotions triggered by an IT event into four categories, i.e. achievement, challenge, loss, and deterrence emotions. The achievement and challenge emotions are experienced when the users perceive an IT as an 
opportunity that might generate positive outcomes, such as happiness and excitement (Beaudry \& Pinsonneault, 2010). The achievement emotions refer to the users' pleasant feeling when they are able to achieve their goal by using the IT with very little effort (Lee, Xiong, \& Hu, 2012; Beaudry \& Pinsonneault, 2010). Challenge emotions could enhance users' positive attitudes toward the technology and help them achieve their goals (Lee et al., 2012; Beaudry \& Pinsonneault, 2005). A new IT which is perceived as a threat would be likely to trigger loss or deterrence emotions (Beaudry \& Pinsonneault, 2010). When individuals lack control over their expected outcomes from the new technology, they are likely to experience loss emotions such as anger, disappointment and frustration. Finally, when users have some control over their expected outcomes, their emotional reactions fall into the deterrence aspect, represented by anxiety, fear, worry, distress, etc. (Beaudry \& Pinsonneault, 2010).

Accordingly, the above-mentioned four distinct classes of users' emotional responses are hypothesised to be related to Internet usage.

H8: Individuals' continuance intention to use the Internet is positively related to their (a) achievement and (b) challenge emotions, but negatively related to their $(c)$ loss and $(d)$ deterrence emotions.

Based on the above hypotheses, Figure 2 presents the emotional-TAM model (ETAM) which depicts the main effects. A number of moderating effects were also tested as discussed below.

Figure 2 Research framework: E-TAM

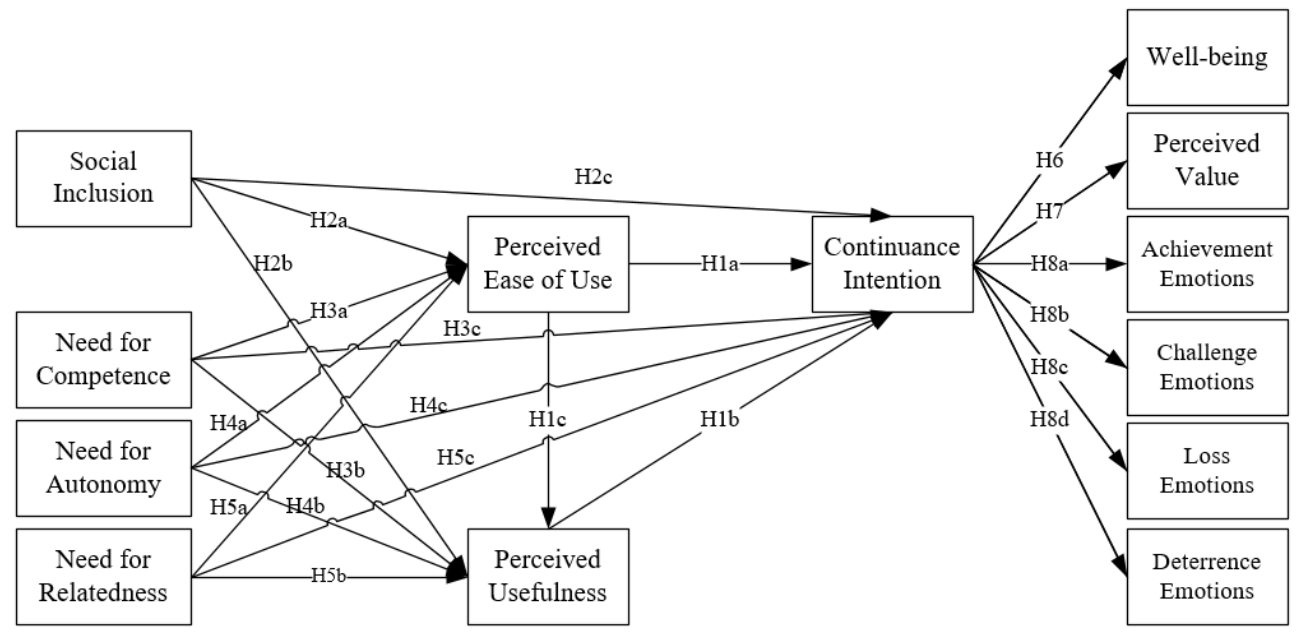

\subsection{Moderators}

The mechanism of psychological factors in the context of technology acceptance and use is complex and varies among individuals. Personal attributes may play a role in influencing the hypothesised relationships (H1-H8). This section reviews three categories of individual differences which potentially moderate the main relationships hypothesised above (Figure 2). Nine moderators will be tested in the following sections with the aim of exploring and examining potential effects. 


\subsubsection{Internet use behaviour and expertise}

The success of ICT implementation is not only determined by the initial adoption decision, but is also influenced by long-term use and continuance intention, which is shaped by users' experience and knowledge gained over time (Venkatesh \& Bala, 2008; Venkatesh, 2000). Initial judgement anchors perceived ease of use in the pre-adoption stage (Venkatesh \& Bala, 2008; Venkatesh, 2000). However, this judgement would be adjusted after the users gained experience by using the target system (Venkatesh \& Bala, 2008; Venkatesh, 2000). Therefore, the influences of PU and PEOU on intention would be moderated by the level of use behaviour and expertise. In the Action Identification Theory of human behaviour, highlevel action identity refers to the individuals' goals and plans toward a certain action, while low-level action identity describes their means to achieve these goals and plans (Vallacher \& Kaufman, 1996; Venkatesh \& Bala, 2008). In the context of acceptance, PU and PEOU represent high-level and low-level action identities respectively (Venkatesh \& Bala, 2008). By using technology, users are forming assessments of goal achieving possibilities based on the knowledge and experience gained from low-level actions (Venkatesh \& Davis, 2000; Davis \& Venkatesh, 2004; Venkatesh \& Bala, 2008). Consequently, the role of PEOU switches from forming BI in the early stage of technology adoption to mainly influencing PU in a later stage (Venkatesh \& Bala, 2008). Empirical evidence has suggested that experienced individuals' attitude toward websites were more affected by perceived usefulness, whereas the less-experienced users focused more on perceived ease of use (Castañeda, Muñoz-Leiva, \& Luque, 2007). In the case of Internet use, individuals may have an initial judgement based on their perception of the easiness of use in the early stage of acceptance. With Internet use experience gained at a later stage, their perception of ease-of-use will affect their continuance intention indirectly through perceived usefulness.

The users' beliefs and reactions toward using the Internet will be influenced by Internet experience as well. Firstly, societal factors have complex and contingent effects on technology acceptance, which may alter users' intention in the early stage of technology use (Venkatesh \& Davis, 2000; Venkatesh et al., 2003). The influences of societal factors on users' intention and perceived usefulness would attenuate with users' increased experience (Venkatesh \& Davis, 2000). Additionally, users' psychological states, such as the satisfaction of the three SDT-based needs, can form intrinsic motivations for technology acceptance and usage. Intrinsic motivations would be diminished by introducing extrinsic motivations or by controlling external conditions (Gagné \& Deci, 2005; Ryan \& Deci, 2000b; Davis, Bagozzi, \& Warshaw, 1992). For experienced users, extrinsic motivations could play a relatively higher role when it comes to determining the individuals' intention on technology use (Venkatesh \& Bala, 2008). As such the influential effects of psychological need fulfilment may diminish with increased Internet experience. In terms of outcomes, prior experience with an IS/IT would enable people to clearly and confidently evaluate the value of a new IS/IT (Yu et al., 2015; Kim, 2008). Experience has been shown to significantly increase the positive effect of perceived usefulness on users' perceived value of the media tablet (Yu et al., 2015). Experienced Internet users are more capable of effectively taking advantage of Internet services with less effort devoted to it (Nysveen and Pedersen, 2004). Therefore, similarly to the perceived value, the other positive outcomes such as well-being, achievement emotions, and challenge emotions may increase among experienced Internet users.

Following the above, Internet use behaviour (USE) and expertise (IE) are expected to be significant moderators. Specifically, a high degree of Internet use behaviour and expertise strengthens the relationship between PEOU and PU and the relationship between PU and CI, and dampens the relationship between PEOU and CI. Also, a high level of Internet use behaviour and expertise dampens the psychological needs, strengthening the positive outcomes of Internet use, and dampening the negative ones.

\subsubsection{Demographic characteristics: age and gender}

Age moderates most of the key relationships of technology acceptance theories such 
as the UTAUT, TPB, and Innovation Diffusion Theory (IDT) (moderating the effects of relative advantage and image on adoption and usage) (Venkatesh et al., 2003; Venkatesh et al., 2012a; Morris \& Venkatesh, 2000). Gender also has a strong impact on individuals' beliefs and behaviours, moderating the relationships between PEOU, PU, and social influences and behavioural intention (Venkatesh et al., 2003; Venkatesh \& Morris, 2000). The relationship between perceived ease of use and intention has been found to be stronger for female and older users, whereas the influence of perceived usefulness on intention was stronger for men and younger users (Venkatesh et al., 2003). PU is more important than PEOU in determining Internet continuance use intention for the young and male users (Venkatesh et al., 2003; Venkatesh \& Morris, 2000).

This paper proposes a further exploration of the role of age and gender in moderating the effects of social and psychological factors on ICT use. The relationship between social influence and behavioural intention is greater for women and the older workers, though only for the less-experienced workers under mandatory conditions (Venkatesh et al., 2003). Female users are more affected by social factors since they may adopt and use a technology with the aim of being more socially included (Hwang, 2010; Gefen \& Ridings, 2005; Venkatesh \& Morris, 2000). Accordingly, social inclusion has stronger effects on Internet acceptance and use among women. Older age has been shown to significantly strengthen the direct negative impact of social exclusion on well-being (Dennis et al., 2016). However, this study did not support the moderating effect of age on the indirect relationship between social exclusion and well-being via technology use (Dennis et al., 2016). Given that the moderation effects by demographic characteristics on the relationships between psychological factors and technology use have not yet been comprehensively tested, this paper proposes to examine age and gender in the context of the E-TAM framework. Following the above, the relationship between the psychological antecedents and outcomes on Internet acceptance are expected to be weaker for individuals who are younger or who are male.

\subsubsection{Personality traits}

Personality refers to the pattern of one's behaviour and the unique facets and traits that define the essence of human beings (Devaraj, Easley, \& Crant, 2008; Venkatesh, Sykes, \& Venkatraman, 2012b). Personality traits determine an individual's thoughts and actions reacting to different situations (Terzis, Moridis, \& Economides, 2012). The motivational mechanism that underlies human behaviour is manifested via satisfaction of the psychological needs and interacts with their personality development and well-being (Van den Broeck et al., 2010; Deci \& Ryan, 2000; Ryan \& Deci, 2000c). Personality traits have been found to affect the users' emotional and psychological conditions, which consequently shape their experience of and behaviours in consumption and technology use, e.g. (Desmet \& Hekkert, 2007; Munzel et al., 2017). In technology acceptance studies, a number of variables representing personality traits have been introduced. For instance, personal innovativeness (Venkatesh et al., 2012b; $\mathrm{Wu} \& \mathrm{Ke}, 2015$ ), individual playfulness (Wu \& Ke, 2015; Terzis et al., 2012), and the Big-5 personality traits (Devaraj et al., 2008; Sykes, Venkatesh, \& Rai, 2011; Terzis et al., 2012).

In this study, we adopt the Big-5 Personality Traits Model (Big-5), which is parsimonious, but sufficiently comprehensive. The model comprises five facets of human personality, namely extroversion, agreeableness, conscientiousness, neuroticism, imagination / openness (Costa \& MacCrae, 1992; Donnellan et al., 2006). Table 1 summarises the empirically supported influential and moderating effects of the five facets of Big-5 personality on technology acceptance models. The majority of current IS/IT empirical studies have simply hypothesised that the traits influence some or all of the core technology acceptance constructs. The results and directions of effects vary among the studies, depending on their research contexts and research objects. These personality traits performed even better than technology acceptance constructs, i.e. performance expectancy, effort expectancy, social influence, and facilitating conditions (Chong et al., 2015). On the other hand, the work of Devaraj et al. (2008) introduced the five personality traits as both influencing and moderating 
variables. Their findings supported the idea that a high degree of extroversion, agreeableness, and conscientiousness strengthens the positive relationship of subjective norm and perceived usefulness and behavioural intention (Devaraj et al., 2008).

Table 1 Relationships among Big-5 personality traits and technology acceptance variables

\begin{tabular}{|c|c|c|}
\hline Personality traits \& Definitions & Path & Supportive evidence \\
\hline \multirow{4}{*}{$\begin{array}{l}\text { Extroversion }(\boldsymbol{E}) \\
\text { The tendency to actively engage in social } \\
\text { activities: comprises facets of friendliness, } \\
\text { gregariousness, assertiveness, activity level, } \\
\text { excitement seeking, and cheerfulness (Donnellan } \\
\text { et al., 2006; Costa \& MacCrae, 1992; Barrick \& } \\
\text { Mount, 1991; Venkatesh et al., 2012b). }\end{array}$} & $\mathrm{SN} \rightarrow \mathrm{BI}$ & (Devaraj et al., 2008) \\
\hline & $\mathrm{E} \rightarrow \mathrm{PU}$ & (Svendsen et al., 2013) \\
\hline & $\mathrm{E} \rightarrow \mathrm{USE}$ & (Venkatesh et al., 2012b) \\
\hline & $\begin{array}{l}\mathrm{E} \rightarrow \text { Perceived } \\
\text { importance }\end{array}$ & (Terzis et al., 2012) \\
\hline \multirow{4}{*}{$\begin{array}{l}\text { Agreeableness }(\boldsymbol{A}) \\
\text { The degree of compassionate interpersonal } \\
\text { orientation: comprises facets of trust, morality, } \\
\text { altruism, cooperation, modesty, and sympathy } \\
\text { (Devaraj et al., 2008; Donnellan et al., 2006). }\end{array}$} & $\mathrm{SN} \rightarrow \mathrm{BI}$ & (Devaraj et al., 2008) \\
\hline & $\mathrm{A} \rightarrow \mathrm{PU}$ & $\begin{array}{l}\text { (Devaraj et al., 2008; Terzis et al., } \\
\text { 2012) }\end{array}$ \\
\hline & $\mathrm{A} \rightarrow \mathrm{PEOU}$ & $\begin{array}{l}\text { (Terzis et al., 2012; Özbek et al., } \\
\text { 2014) }\end{array}$ \\
\hline & $\mathrm{A} \rightarrow \mathrm{SN}$ & (Terzis et al., 2012) \\
\hline \multirow{4}{*}{$\begin{array}{l}\text { Conscientiousness }(\boldsymbol{C}) \\
\text { The degree of organisation, persistence, and } \\
\text { being goal-oriented: comprises facets of self- } \\
\text { efficacy, orderliness, dutifulness, achievement } \\
\text { striving, self-discipline, and cautiousness } \\
\text { (Devaraj et al., 2008; Donnellan et al., 2006; } \\
\text { Barrick \& Mount, 1991; Costa \& MacCrae, } \\
\text { 1992). }\end{array}$} & $\mathrm{SN} \rightarrow \mathrm{BI}$ & (Devaraj et al., 2008) \\
\hline & $\mathrm{PU} \rightarrow \mathrm{BI}$ & (Devaraj et al., 2008) \\
\hline & $\mathrm{C} \rightarrow \mathrm{PEOU}$ & (Terzis et al., 2012) \\
\hline & $\mathrm{C} \rightarrow \mathrm{USE}$ & $\begin{array}{l}\text { (Venkatesh et al., 2012b; Sykes et } \\
\text { al., 2011) }\end{array}$ \\
\hline \multirow{3}{*}{\begin{tabular}{|l|} 
Neuroticism $(N)$ \\
The degree of emotional instability and \\
experiencing constant negative feelings: \\
comprises facets of anxiety, anger, depression, \\
self-consciousness, immoderation, and \\
vulnerability (Donnellan et al., 2006; Venkatesh \\
et al., 2012b; Devaraj et al., 2008). \\
\end{tabular}} & $\mathrm{N} \rightarrow \mathrm{PU}$ & $\begin{array}{l}\text { (Devaraj et al., 2008; Terzis et al., } \\
\text { 2012) }\end{array}$ \\
\hline & $\mathrm{N} \rightarrow \mathrm{USE}$ & (Sykes et al., 2011) \\
\hline & $\begin{array}{l}\mathrm{N} \rightarrow \text { Goal } \\
\text { expectancy }\end{array}$ & $\begin{array}{l}\text { (Terzis et al., 2012; Özbek et al., } \\
\text { 2014) }\end{array}$ \\
\hline \multirow{3}{*}{$\begin{array}{l}\text { Imagination/Openness (I) } \\
\text { The degree of flexibility of thought and openness } \\
\text { to new ideas: comprises facets of imagination, } \\
\text { artistic interest, emotionality, adventurousness, } \\
\text { intellect, and liberalism (Donnellan et al., 2006; } \\
\text { Venkatesh et al., 2012b; Devaraj et al., 2008). } \\
\end{array}$} & $\mathrm{I} \rightarrow \mathrm{PEOU}$ & $\begin{array}{l}\text { (Svendsen et al., 2013; Özbek et } \\
\text { al., 2014) }\end{array}$ \\
\hline & $\mathrm{I} \rightarrow \mathrm{USE}$ & $\begin{array}{l}\text { (Venkatesh et al., 2012b; Sykes et } \\
\text { al., 2011) }\end{array}$ \\
\hline & $\begin{array}{l}\mathrm{I} \rightarrow \text { Perceived } \\
\text { importance }\end{array}$ & (Terzis et al., 2012) \\
\hline
\end{tabular}

Notes: $S N=$ Social Influence/Subjective Norm; $P=$ positive effect $; N=$ negative effect;

Significant at $p: *<.05 ; * *<.01 ; * * *<.001$

\section{Methodology}

\subsection{Data collection and sampling}

A quantitative approach was adopted. The questionnaire was made available online and data collected using a consumer panel. An independent company organised the respondent recruitment, consisting of Internet users in the United States. The authors did not have direct access to the respondents, which preserved their anonymity (ethical approval was obtained in accordance with the University's established procedures prior to the study taking place). Respondents were given the URL of the online survey and were asked to complete it, following the instructions given on the introductory page. 670 full questionnaires were initially received. Prior to the main survey, a pilot study was carried out with 10 participants. Based on the evaluation of this pilot study and the average completion time of the main study, 
collected questionnaires that had been completed in less than five minutes were excluded from the dataset. Additionally, this study removed questionnaires completed by selecting the same answer for most of the scaled measurement items, including the 11 reversed ones. By applying the above-stated criteria in the data screening process, 615 completed questionnaires were entered into the analysis. Table 2 illustrates the participants' profile.

Table 2 Demographic profile of respondents

\begin{tabular}{|c|c|c|c|}
\hline $\begin{array}{l}\text { Demographic } \\
\text { characteristic }\end{array}$ & Type & $\begin{array}{l}\text { Frequency } \\
(n=615)\end{array}$ & $\begin{array}{l}\text { Percentage } \\
(\%)\end{array}$ \\
\hline \multirow[t]{2}{*}{ Gender } & Male & 266 & $43.3 \%$ \\
\hline & Female & 349 & $56.7 \%$ \\
\hline \multirow[t]{5}{*}{ Age } & $20-29$ & 69 & $11.2 \%$ \\
\hline & $30-39$ & 127 & $20.7 \%$ \\
\hline & $40-49$ & 114 & $18.5 \%$ \\
\hline & $50-59$ & 139 & $22.6 \%$ \\
\hline & 60 or over & 166 & $27.0 \%$ \\
\hline \multirow{8}{*}{$\begin{array}{l}\text { Current } \\
\text { employment status }\end{array}$} & Full-time employed & 258 & $42.0 \%$ \\
\hline & \begin{tabular}{|l|} 
Part-time employed \\
\end{tabular} & 64 & $10.4 \%$ \\
\hline & Out of work (looking for work) & 26 & $4.2 \%$ \\
\hline & Out of work (not looking for work) & 6 & $1.0 \%$ \\
\hline & Homemaker & 77 & $12.5 \%$ \\
\hline & Student & 16 & $2.6 \%$ \\
\hline & Retired & 125 & $20.3 \%$ \\
\hline & Unable to work & 43 & $7.0 \%$ \\
\hline \multirow[t]{8}{*}{ Ethnicity } & African American & 65 & $10.6 \%$ \\
\hline & Native American & 6 & $1.0 \%$ \\
\hline & USA White & 452 & $73.5 \%$ \\
\hline & Asian American & 28 & $4.6 \%$ \\
\hline & Hispanic American & 37 & $6.0 \%$ \\
\hline & Multiracial & 8 & $1.3 \%$ \\
\hline & Other White Background & 15 & $2.4 \%$ \\
\hline & Other & 4 & $0.7 \%$ \\
\hline \multirow{8}{*}{$\begin{array}{l}\text { Education } \\
\text { attainment }\end{array}$} & Some high school or less & 12 & $2.0 \%$ \\
\hline & High school graduate or equivalent & 118 & $19.2 \%$ \\
\hline & Vocational/technical school & 54 & $8.8 \%$ \\
\hline & Some college, but no degree & 157 & $25.5 \%$ \\
\hline & College graduate & 156 & $25.4 \%$ \\
\hline & Some graduate school & 22 & $3.6 \%$ \\
\hline & Graduate degree & 78 & $12.7 \%$ \\
\hline & Professional degree & 18 & $2.9 \%$ \\
\hline \multirow[t]{3}{*}{ Residence area } & Urbanized area & 256 & $41.6 \%$ \\
\hline & Urban cluster & 231 & $37.6 \%$ \\
\hline & Rural area & 128 & $20.8 \%$ \\
\hline \multirow[t]{5}{*}{ Household income } & $\$ 0-\$ 24,999$ & 114 & $18.5 \%$ \\
\hline & $\$ 25,000-\$ 49,999$ & 161 & $26.2 \%$ \\
\hline & $\$ 50,000-\$ 74,999$ & 138 & $22.4 \%$ \\
\hline & $\$ \$ 75,000-\$ 99,999$ & 95 & $15.4 \%$ \\
\hline & More than $\$ 100,000$ & 107 & $17.4 \%$ \\
\hline
\end{tabular}

\subsection{Measurement items}

The questionnaire consisted of 68 measurement items for the main constructs and moderators.

Table 3 presents the measure items of each construct. Items for the TAM variables, i.e. PEOU, PU, and CI, were adapted from Davis (1989) and Venkatesh (2000). Social inclusion items were adopted from Richardson and Le Grand (2002), while items for the psychological needs for competence, autonomy, and relatedness were adapted from the Work- 
related Basic Need Satisfaction scale (Van den Broeck et al., 2010). Items measuring the well-being and perceived value were adapted for the Internet users in the post-adoption context from El Hedhli et al. (2013) and Okada (2005) respectively. Lastly, we included ten potential emotional responses to using the Internet (Beaudry \& Pinsonneault, 2010). When it came to the moderators, this study measured both the subjective and objective dimensions of Internet use. Respondents were asked about the time spent on the Internet on a daily basis, and the degree to which they perceive themselves as heavy users (Dishaw \& Strong, 1999; Mathwick \& Rigdon, 2004). Subjective Internet expertise was also measured to describe the degree to which participants perceived themselves to be knowledgeable and informed about the Internet (Dishaw \& Strong, 1999; Oliver \& Bearden, 1985). As far as personality characteristics are concerned, Credé et al. (2012) reviewed eight measures of the Big-5 personalities and suggested that "even slightly longer measures can substantially increase the validity of research findings". Taking into account the length, scale validity, and reliability of the questionnaire, this study used the 20-item Mini International Personality Item Pool by Donnellan et al. (2006).

\subsection{Data analysis strategy}

In our data analysis we followed the process suggested by Hair et al. (2014) and by Gasking (2016). SPSS v.23 and SPSS Amos v.24 were used for the statistical analysis of the main hypotheses and moderation effects. Firstly, a confirmatory factor analysis was undertaken to ensure construct reliability and validity. The model fit was satisfactory (Table 3). The Factor loading (>0.7), construct reliability (C.R.; >0.7), average variance extracted (AVE; >0.5), and Cronbach's $\alpha(>0.7)$ of each measured variable suggested adequate reliability (Hair Jr et al., 2014). There was no convergent validity issue with the model (Table 4). Structural equation modelling was employed to test hypotheses H1-H8 (Table 5). As the structural model has been established, this study proceeded to explore the moderation effects. A multi-group analysis approach according to Hair Jr et al. (2014) was applied to the SEMbased research model. The two-step cluster function in SPSS was used to classify the samples into two groups, representing low and high levels for each moderating index (except for gender, which was classified into two groups). A partial metric invariance test was required to ensure the factor loading equivalence of the two clusters of each moderator. Each pair of datasets was assigned to E-TAM and then the unconstrained model, measurement weights model, and structural weights models were generated. This analysis achieved the equivalence of factor loadings by comparing the unconstrained model and measurement weights model (model comparison non-significant, $\mathrm{p}>0.05$ ). Path relations variance was also ensured by the significant difference between the measurement weights model and the structural weights model reported in the model comparison (model comparison significant, $\mathrm{p}<0.05$ ). Therefore, this study continues to examine the moderation effects.

\section{Table 3 Measure items of constructs}

\begin{tabular}{|c|c|c|c|c|}
\hline Measurement Item & Loading & C.R. & AVE & Cronbach's $\alpha$ \\
\hline \multicolumn{5}{|l|}{ Perceived Ease of Use (Venkatesh, 2000) } \\
\hline Using the Internet is clear and easy to understand. & 0.821 & \multirow[t]{4}{*}{0.927} & \multirow[t]{4}{*}{0.761} & \multirow[t]{4}{*}{0.925} \\
\hline Using the Internet does not require a lot of my effort. & 0.840 & & & \\
\hline I find the Internet to be easy to use. & 0.932 & & & \\
\hline I find it easy to get the Internet to do what I want it to do. & 0.892 & & & \\
\hline \multicolumn{5}{|l|}{ Perceived Usefulness (Venkatesh, 2000) } \\
\hline $\begin{array}{l}\text { Using the Internet improves my performance in my personal and work- } \\
\text { related tasks. }\end{array}$ & 0.880 & \multirow[t]{3}{*}{0.938} & \multirow[t]{3}{*}{0.834} & \multirow[t]{3}{*}{0.936} \\
\hline $\begin{array}{l}\text { Using the Internet in my personal and work-related tasks increases my } \\
\text { productivity. }\end{array}$ & 0.935 & & & \\
\hline $\begin{array}{l}\text { Using the Internet enhances my effectiveness in my personal and work- } \\
\text { related tasks. }\end{array}$ & 0.924 & & & \\
\hline \multicolumn{5}{|l|}{ Continuance Intention (Venkatesh, 2000) } \\
\hline I intend to continue using the Internet in the future. & 0.877 & \multirow[t]{2}{*}{0.868} & \multirow[t]{2}{*}{0.767} & \multirow[t]{2}{*}{0.868} \\
\hline I plan to continue to use the Internet frequently. & 0.875 & & & \\
\hline
\end{tabular}




\begin{tabular}{|c|c|c|c|c|}
\hline How do you feel about your affordability of food? & 0.807 & \multirow[t]{5}{*}{0.884} & \multirow[t]{5}{*}{0.607} & \multirow[t]{5}{*}{0.898} \\
\hline How do you feel about your access to affordable accommodation? & 0.867 & & & \\
\hline How do you feel about your ability to obtain credit? & 0.660 & & & \\
\hline How do you feel about your access to health care? & 0.705 & & & \\
\hline How do you feel about your affordability of transportation costs? & 0.836 & & & \\
\hline \multicolumn{5}{|l|}{ Need for Competence (Van den Broeck et al., 2010) } \\
\hline Using the Internet makes me feel competent. & 0.866 & \multirow[t]{3}{*}{0.915} & \multirow[t]{3}{*}{0.783} & \multirow[t]{3}{*}{0.913} \\
\hline $\begin{array}{l}\text { Using the Internet makes me feel that I can be good at the things that I } \\
\text { do. }\end{array}$ & 0.917 & & & \\
\hline $\begin{array}{l}\text { Using the Internet makes me feel that I could even accomplish the most } \\
\text { difficult objectives. }\end{array}$ & 0.870 & & & \\
\hline \multicolumn{5}{|l|}{ Need for Autonomy (Van den Broeck et al., 2010) } \\
\hline Using the Internet gives me the opportunity to do things differently. & 0.869 & \multirow[t]{2}{*}{0.890} & \multirow[t]{2}{*}{0.802} & \multirow[t]{2}{*}{0.889} \\
\hline $\begin{array}{l}\text { Using the Internet gives me the opportunity to do things the way I } \\
\text { really want. }\end{array}$ & 0.921 & & & \\
\hline \multicolumn{5}{|l|}{ Need for Relatedness (Van den Broeck et al., 2010) } \\
\hline Using the Internet makes me feel part of a group. & 0.876 & \multirow[t]{3}{*}{0.927} & \multirow[t]{3}{*}{0.809} & \multirow[t]{3}{*}{0.921} \\
\hline Using the Internet helps me to mix with other people. & 0.936 & & & \\
\hline $\begin{array}{l}\text { Using the Internet gives me the opportunity to talk with people about } \\
\text { things that really matter to me. }\end{array}$ & 0.885 & & & \\
\hline \multicolumn{5}{|l|}{ Well-being (El Hedhli et al., 2013) } \\
\hline The Internet plays a very important role in my social well-being. & 0.875 & \multirow[t]{2}{*}{0.857} & \multirow[t]{2}{*}{0.749} & \multirow[t]{2}{*}{0.783} \\
\hline $\begin{array}{l}\text { The Internet plays an important role in enhancing the quality of my life } \\
\text { in my community. }\end{array}$ & 0.856 & & & \\
\hline \multicolumn{5}{|l|}{ Perceived Value (Okada, 2005) } \\
\hline Overall, what is the value of the Internet in your life? & 0.906 & \multirow[t]{3}{*}{0.829} & \multirow[t]{3}{*}{0.621} & \multirow[t]{3}{*}{0.806} \\
\hline How well-off are you with the Internet in your life? & 0.749 & & & \\
\hline How would you feel if you did not have access to the Internet? & 0.694 & & & \\
\hline \multicolumn{5}{|l|}{ Achievement Emotions (Beaudry \& Pinsonneault, 2010) } \\
\hline Satisfaction & 0.895 & \multirow[t]{3}{*}{0.899} & \multirow[t]{3}{*}{0.748} & \multirow[t]{3}{*}{0.899} \\
\hline Pleasure & 0.847 & & & \\
\hline enjoyment & 0.851 & & & \\
\hline \multicolumn{5}{|l|}{ Challenge Emotions (Beaudry \& Pinsonneault, 2010) } \\
\hline playfulness & 0.778 & 0.765 & 0.619 & 0.761 \\
\hline flow & 0.796 & & & \\
\hline Loss Emotions (Beaudry \& Pinsonneault, 2010) & & & & \\
\hline disappointment & 0.922 & 0.892 & 0.805 & 0.890 \\
\hline frustration & 0.872 & & & \\
\hline Deterrence Emotions (Beaudry \& Pinsonneault, 2010) & & & & \\
\hline fear & 0.895 & 0.941 & 0.842 & 0.940 \\
\hline worry & 0.941 & & & \\
\hline distress & 0.916 & & & \\
\hline
\end{tabular}

Notes: Items measured by 7-point Likert scale: Strongly disagree; Disagree; Somewhat disagree; Neither agree nor disagree; Somewhat agree; Agree; Strongly agree.

Method: M.L.; Model fit: $\chi 2(551)=1200.367, C M I N / D F=2.179, G F I=0.904, C F I=0.967, R M S E A=0.044$.

Table 4 Convergent validity test

\begin{tabular}{|l|l|l|l|l|l|l|l|l|l|l|l|l|l|}
\hline & $\mathbf{1}$ & $\mathbf{2}$ & $\mathbf{3}$ & $\mathbf{4}$ & $\mathbf{5}$ & $\mathbf{6}$ & $\mathbf{7}$ & $\mathbf{8}$ & $\mathbf{9}$ & $\mathbf{1 0}$ & $\mathbf{1 1}$ & $\mathbf{1 2}$ & $\mathbf{1 3}$ \\
\hline Social Inclusion & 0.779 & & & & & & & & & & & & \\
\hline Need for Competence & 0.284 & 0.885 & & & & & & & & & & & \\
\hline Need for Autonomy & 0.291 & 0.852 & 0.895 & & & & & & & & & & \\
\hline Need for Relatedness & 0.199 & 0.693 & 0.623 & 0.899 & & & & & & & & & \\
\hline Perceived Ease of Use & 0.343 & 0.570 & 0.568 & 0.461 & 0.872 & & & & & & & & \\
\hline Perceived Usefulness & 0.295 & 0.674 & 0.589 & 0.606 & 0.672 & 0.913 & & & & & & & \\
\hline Continuance Intention & 0.334 & 0.527 & 0.537 & 0.394 & 0.762 & 0.590 & 0.876 & & & & & & \\
\hline Well-Being & 0.199 & 0.667 & 0.592 & 0.814 & 0.508 & 0.645 & 0.411 & 0.866 & & & & & \\
\hline Perceived Value & 0.324 & 0.661 & 0.655 & 0.580 & 0.688 & 0.664 & 0.734 & 0.672 & 0.788 & & & & \\
\hline Achievement Emotions & 0.414 & 0.662 & 0.639 & 0.552 & 0.699 & 0.591 & 0.688 & 0.602 & 0.756 & 0.865 & & & \\
\hline Challenge Emotions & 0.230 & 0.658 & 0.661 & 0.683 & 0.461 & 0.572 & 0.339 & 0.703 & 0.568 & 0.633 & 0.787 & & \\
\hline
\end{tabular}


\begin{tabular}{|l|c|c|c|c|c|c|c|c|c|c|c|c|}
\hline Loss Emotions & -0.221 & -0.158 & -0.142 & -0.062 & -0.348 & -0.156 & -0.347 & -0.093 & -0.276 & -0.336 & 0.064 & 0.897 \\
\hline
\end{tabular}

\begin{tabular}{|l|l|l|l|l|l|l|l|l|l|l|l|l|l|}
\hline Deterrence Emotions & -0.203 & -0.076 & -0.077 & 0.037 & -0.262 & -0.086 & -0.328 & 0.012 & -0.212 & -0.293 & 0.126 & 0.840 & 0.918 \\
\hline
\end{tabular}

Note: Figures in the diagonal represent the square root of the average variance extracted (AVE); those below the diagonal represent the correlations between the constructs.

\section{Results and findings}

\subsection{Path analysis}

The E-TAM framework satisfied the model fit criteria (Table 5). The $\mathrm{R}^{2}$, direct effects, indirect effects, and total effects suggested that the research model explained a sufficient amount of variance (Table 6). The majority of hypotheses were accepted except for $\mathrm{H} 2 \mathrm{~b}, \mathrm{H} 3 \mathrm{c}$, and H4b. More specifically, all TAM effects (H1) were statistically supported. Perceived Ease of Use showed significant and strong relationships with Continuance Intentions (H1a) and Perceived Usefulness (H1c). The relationship between Perceived Usefulness and Continuance Intentions (H1b) was significant, but weaker than that between Perceived Ease of Use and Continuance Intentions. The proposed antecedents, i.e. Social Inclusion, Need for Competence, Autonomy and Relatedness, were positively and significantly related to users' perceptions of and Continuance Intention of using the Internet (H2-H5 partially supported). Among the relationships between the four antecedents and Perceived Usefulness, the Need for Competence was the strongest, whereas Social Inclusion and the Need for Autonomy were not significant. The needs for Competence and Autonomy were significantly related to Perceived Ease of Use. When it came to Continuance Intention, Social Inclusion and the Needs for Autonomy and Relatedness showed significant relationships. Lastly, the statistical analysis supported the significance of the six-proposed psychological and emotional outcomes of using the Internet (H6-H8 all significant at the $<0.01$ level). The Continuance Intention of Internet was positively related to Well-being, Perceived Value, Achievement Emotions, and Challenge Emotions. The relationship of Continuance Intentions with negative emotions, i.e. Loss Emotions and Deterrence Emotions, was negative with path coefficients much smaller than positive outcomes. 
Table 5 Statistical results of hypotheses test: structural equation model (H1-H8)

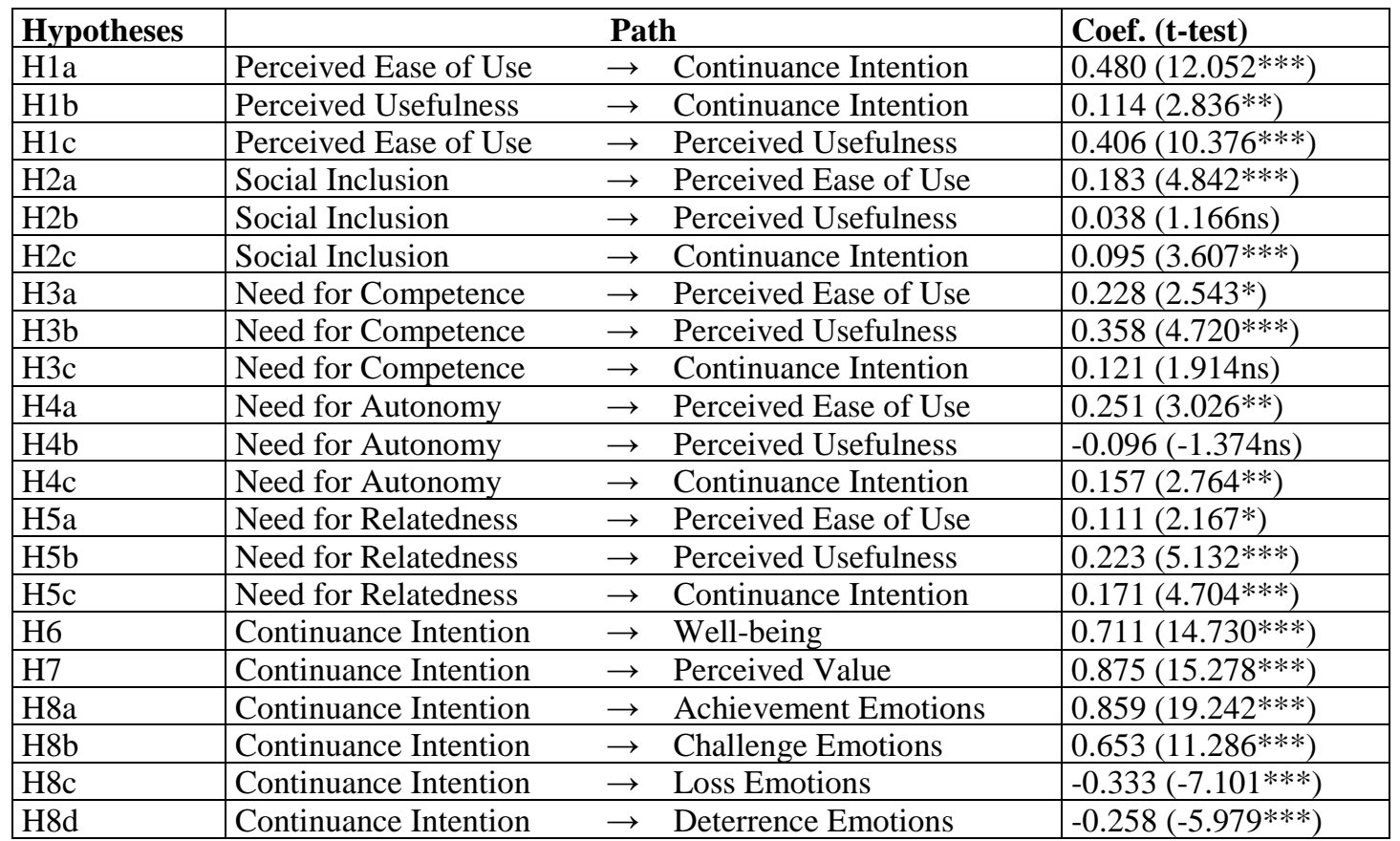

Method: M.L.; Model fit: $\chi 2$ (602) = 2530.516, CMIN/DF = 4.204, CFI=0.901, RMSEA=0.072.

Significant at $p: n s \geq .05 ; *<.05 ; * *<.01 ; * * *<.001$

Table 6 E-TAM: $\mathbf{R}^{2}$ and direct, indirect, and total effects

\begin{tabular}{|c|c|c|c|c|c|}
\hline Dependent Variable & $\mathbf{R}^{2}$ & Independent Variable & $\begin{array}{l}\text { Direct } \\
\text { Effect }\end{array}$ & $\begin{array}{r}\text { Indirect } \\
\text { Effect }\end{array}$ & $\begin{array}{r}\text { Total } \\
\text { Effect }\end{array}$ \\
\hline \multirow[t]{4}{*}{ Perceived Ease of Use } & \multirow[t]{4}{*}{0.386} & Social Inclusion & 0.183 & 0.000 & 0.183 \\
\hline & & Need for Competence & 0.228 & 0.000 & 0.228 \\
\hline & & Need for Autonomy & 0.251 & 0.000 & 0.251 \\
\hline & & Need for Relatedness & 0.111 & 0.000 & 0.111 \\
\hline \multirow[t]{5}{*}{ Perceived Usefulness } & \multirow[t]{5}{*}{0.603} & Social Inclusion & 0.038 & 0.074 & 0.112 \\
\hline & & Need for Competence & 0.358 & 0.093 & 0.450 \\
\hline & & Need for Autonomy & -0.096 & 0.102 & 0.006 \\
\hline & & Need for Relatedness & 0.223 & 0.045 & 0.268 \\
\hline & & Perceived Ease of Use & 0.406 & 0.000 & 0.406 \\
\hline \multirow[t]{6}{*}{ Continuance Intention } & \multirow[t]{6}{*}{0.839} & Social Inclusion & 0.095 & 0.101 & 0.195 \\
\hline & & Need for Competence & 0.121 & 0.161 & 0.282 \\
\hline & & \begin{tabular}{|l|} 
Need for Autonomy \\
\end{tabular} & 0.157 & 0.121 & 0.278 \\
\hline & & Need for Relatedness & 0.171 & 0.084 & 0.255 \\
\hline & & Perceived Ease of Use & 0.480 & 0.046 & 0.526 \\
\hline & & Perceived Usefulness & 0.114 & 0.000 & 0.114 \\
\hline \multirow[t]{7}{*}{ Well-Being } & \multirow[t]{7}{*}{0.505} & Social Inclusion & 0.000 & 0.139 & 0.139 \\
\hline & & Need for Competence & 0.000 & 0.200 & 0.200 \\
\hline & & \begin{tabular}{|l|} 
Need for Autonomy \\
\end{tabular} & 0.000 & 0.198 & 0.198 \\
\hline & & Need for Relatedness & 0.000 & 0.181 & 0.181 \\
\hline & & Perceived Ease of Use & 0.000 & 0.374 & 0.374 \\
\hline & & \begin{tabular}{|l|} 
Perceived Usefulness \\
\end{tabular} & 0.000 & 0.081 & 0.081 \\
\hline & & Continuance Intention & 0.711 & 0.000 & 0.711 \\
\hline \multirow[t]{4}{*}{ Perceived Value } & \multirow[t]{4}{*}{0.765} & Social Inclusion & 0.000 & 0.171 & 0.171 \\
\hline & & Need for Competence & 0.000 & 0.246 & 0.246 \\
\hline & & Need for Autonomy & 0.000 & 0.244 & 0.244 \\
\hline & & Need for Relatedness & 0.000 & 0.223 & 0.223 \\
\hline
\end{tabular}




\begin{tabular}{|c|c|c|c|c|c|}
\hline & & Perceived Ease of Use & 0.000 & 0.460 & 0.460 \\
\hline & & Perceived Usefulness & 0.000 & 0.099 & 0.099 \\
\hline & & \begin{tabular}{|l|} 
Continuance Intention \\
\end{tabular} & 0.875 & 0.000 & 0.875 \\
\hline Achievement Emotion & 0.737 & Social Inclusion & 0.000 & 0.168 & 0.168 \\
\hline & & Need for Competence & 0.000 & 0.242 & 0.242 \\
\hline & & Need for Autonomy & 0.000 & 0.239 & 0.239 \\
\hline & & Need for Relatedness & 0.000 & 0.219 & 0.219 \\
\hline & & Perceived Ease of Use & 0.000 & 0.452 & 0.452 \\
\hline & & Perceived Usefulness & 0.000 & 0.097 & 0.097 \\
\hline & & Continuance Intention & 0.859 & 0.000 & 0.859 \\
\hline Challenge Emotion & 0.426 & Social Inclusion & 0.000 & 0.127 & 0.127 \\
\hline & & Need for Competence & 0.000 & 0.184 & 0.184 \\
\hline & & Need for Autonomy & 0.000 & 0.182 & 0.182 \\
\hline & & Need for Relatedness & 0.000 & 0.167 & 0.167 \\
\hline & & Perceived Ease of Use & 0.000 & 0.344 & 0.344 \\
\hline & & Perceived Usefulness & 0.000 & 0.074 & 0.074 \\
\hline & & Continuance Intention & 0.653 & 0.000 & 0.653 \\
\hline Loss Emotion & 0.111 & Social Inclusion & 0.000 & -0.065 & -0.065 \\
\hline & & Need for Competence & 0.000 & -0.094 & -0.094 \\
\hline & & Need for Autonomy & 0.000 & -0.093 & -0.093 \\
\hline & & Need for Relatedness & 0.000 & -0.085 & -0.085 \\
\hline & & Perceived Ease of Use & 0.000 & -0.176 & -0.176 \\
\hline & & Perceived Usefulness & 0.000 & -0.038 & -0.038 \\
\hline & & Continuance Intention & -0.333 & 0.000 & -0.333 \\
\hline Deterrence Emotion & 0.067 & Social Inclusion & 0.000 & -0.050 & -0.050 \\
\hline & & Need for Competence & 0.000 & -0.073 & -0.073 \\
\hline & & Need for Autonomy & 0.000 & -0.072 & -0.072 \\
\hline & & Need for Relatedness & 0.000 & -0.066 & -0.066 \\
\hline & & Perceived Ease of Use & 0.000 & -0.136 & -0.136 \\
\hline & & Perceived Usefulness & 0.000 & -0.029 & -0.029 \\
\hline & & Continuance Intention & -0.258 & 0.000 & -0.258 \\
\hline
\end{tabular}

\subsection{Moderation effects}

Following the analysis of the main effects (H1-H8), this study proceeded to explore the moderation effects of 9 potential moderators. A full metric or partial metric invariance was established for each pair of clusters. Table 7, Table 8, and Table 9 provide an overview of the multi-group analysis. Among the nine moderators, Internet Expertise was the most influential, moderating nine out of 21 paths of the E-TAM model, whereas Extroversion moderated only the effect of Continuance Intention on Challenge Emotions. Moderating effects were more frequently present on the outcomes side of the model, especially when it came to the relationships between Continuance Intention and well-being as well as the different types of emotions. The directions of moderation were broadly consistent with Internet Use Behaviour and Internet Expertise (Table 7). When it came to age, statistical results indicated that among high-age users ( $\geq 40$ years old, 68.1\%), Perceived Ease of Use was less important in influencing Perceived Usefulness and Continuance Intentions. The positive relationship between the Need for Competence and Perceived Usefulness was only significant among senior users, whereas the Need for Relatedness was strongly related to Perceived Usefulness for younger participants ( $\leq 39$ years old, 31.9\%). When using the Internet, females were likely to experience higher degrees of Well-being, Perceived Value, and Challenge Emotions but a slightly lower level of Achievement Emotions than do males (Table 8). Lastly, the majority of the moderation effects of the Big-5 variables were found to be significant on the outcome side of the E-TAM (Table 9). The highly agreeable, conscientious, imaginative, or less neurotic users were more likely to have negative emotional reactions when using the Internet. Internet users who are highly extroverted and conscientious tend to experience more challenge emotions, whereas the more conscientious ones might 
experience fewer achievement emotions. Well-being was enhanced by using the Internet for low-conscientiousness or high-neuroticism individuals, though they might believe the Internet was less valuable. 
Table 7 Moderation analysis: Internet use behaviour and Internet expertise

\begin{tabular}{|c|c|c|c|c|c|c|c|c|}
\hline \multirow[t]{2}{*}{ Path } & \multicolumn{4}{|c|}{ Internet Use Behaviour } & \multicolumn{4}{|c|}{ Internet Expertise } \\
\hline & $\begin{array}{l}\text { Low use behaviour } \\
\text { Coef.(t-test) }\end{array}$ & $\begin{array}{l}\text { High use behaviour } \\
\text { Coef.(t-test) }\end{array}$ & $\Delta \chi^{2}$ & Sig. & $\begin{array}{l}\text { Low expertise } \\
\text { Coef.(t-test) }\end{array}$ & $\begin{array}{l}\text { High expertise } \\
\text { Coef.(t-test) }\end{array}$ & $\Delta \chi^{2}$ & Sig. \\
\hline Perceived Ease of Use $\rightarrow$ Continuance Intention & $0.443(6.851 * * *)$ & $0.561\left(9.869^{* * *}\right)$ & 1.435 & ns & $0.511(10.329 * * *)$ & $0.493\left(6.841^{* * *}\right)$ & 0.188 & ns \\
\hline Perceived Usefulness $\rightarrow$ Continuance Intention & $0.165\left(2.131^{*}\right)$ & $0.042(0.790 \mathrm{~ns})$ & 2.123 & ns & $0.039(0.720 \mathrm{~ns})$ & $0.239(3.444 * * *)$ & 3.145 & ns \\
\hline Perceived Ease of Use $\rightarrow$ Perceived Usefulness & $0.217\left(3.050^{* *}\right)$ & $0.514(10.582 * * *)$ & 18.401 & $* * *$ & $0.351(6.751 * * *)$ & $0.456(7.162 * * *)$ & 6.951 & $* *$ \\
\hline Social Inclusion $\rightarrow$ Perceived Ease of Use & $0.277(3.987 * * *)$ & $0.149\left(3.044^{* *}\right)$ & 4.630 & $*$ & $0.262\left(5.216^{* * *}\right)$ & $0.045(0.660 \mathrm{~ns})$ & 12.984 & $* * *$ \\
\hline Social Inclusion $\rightarrow$ Perceived Usefulness & $0.091(1.451 \mathrm{~ns})$ & $0.021(0.515 n s)$ & 1.012 & ns & $0.021(0.467 \mathrm{~ns})$ & $0.098(1.781 \mathrm{~ns})$ & 0.824 & ns \\
\hline Social Inclusion $\rightarrow$ Continuance Intention & $0.214(3.923 * * *)$ & 0.063 (1.815ns) & 7.897 & $* *$ & $0.125(3.304 * * *)$ & $0.101\left(2.116^{*}\right)$ & 1.996 & ns \\
\hline Need for Competence $\rightarrow$ Perceived Ease of Use & $0.476(2.265 *)$ & $0.180(1.955 \mathrm{~ns})$ & 2.265 & ns & $0.268(1.999 *)$ & $0.176(1.579 \mathrm{~ns})$ & 1.078 & ns \\
\hline Need for Competence $\rightarrow$ Perceived Usefulness & $0.686\left(3.585^{* * *}\right)$ & $0.244\left(3.188^{* *}\right)$ & 5.486 & $*$ & $0.612(4.947 * * *)$ & 0.109 (1.225ns) & 13.344 & $* * *$ \\
\hline Need for Competence $\rightarrow$ Continuance Intention & $-0.018(-0.104 \mathrm{~ns})$ & $0.159(2.386 *)$ & 0.560 & ns & $0.223(2.070 *)$ & $0.028(0.360 \mathrm{~ns})$ & 3.068 & ns \\
\hline Need for Autonomy $\rightarrow$ Perceived Ease of Use & $-0.067(-0.356 \mathrm{~ns})$ & $0.319(3.497 * * *)$ & 2.960 & ns & $0.128(1.078 \mathrm{~ns})$ & $0.323(2.742 * *)$ & 0.791 & ns \\
\hline Need for Autonomy $\rightarrow$ Perceived Usefulness & $-0.267(-1.610 \mathrm{~ns})$ & $-0.104(-1.355 \mathrm{~ns})$ & 0.715 & ns & $-0.286(-2.651 * *)$ & $0.050(0.518 \mathrm{~ns})$ & 5.083 & * \\
\hline Need for Autonomy $\rightarrow$ Continuance Intention & $0.273(1.894 \mathrm{~ns})$ & $0.107(1.621 \mathrm{~ns})$ & 1.286 & ns & $0.099(1.109 \mathrm{~ns})$ & $0.161(1.924 \mathrm{~ns})$ & 0.059 & ns \\
\hline Need for Relatedness $\rightarrow$ Perceived Ease of Use & $0.076(0.863 \mathrm{~ns})$ & $0.045(0.712 \mathrm{~ns})$ & 0.176 & ns & $0.091(1.377 \mathrm{~ns})$ & $0.007(0.081 \mathrm{~ns})$ & 0.959 & ns \\
\hline Need for Relatedness $\rightarrow$ Perceived Usefulness & $0.178(2.352 *)$ & $0.243(4.561 * * *)$ & 0.157 & ns & $0.148(2.530 *)$ & $0.249(3.599 * * *)$ & 0.820 & ns \\
\hline Need for Relatedness $\rightarrow$ Continuance Intention & $0.073(1.122 \mathrm{~ns})$ & $0.201\left(4.211^{* * *}\right)$ & 0.961 & ns & $0.128\left(2.690^{* *}\right)$ & $0.194\left(3.077^{* *}\right)$ & 0.005 & ns \\
\hline Continuance Intention $\rightarrow$ Well-being & $0.520(5.064 * * *)$ & $0.675(11.523 * * *)$ & 21.503 & $* * *$ & $0.591(10.163 * * *)$ & $0.640(7.949 * * *)$ & 8.699 & $* *$ \\
\hline Continuance Intention $\rightarrow$ Perceived Value & $0.893(11.380 * * *)$ & $0.814(12.023 * * *)$ & 2.415 & ns & $0.877(13.766 * * *)$ & $0.707(8.469 * * *)$ & 0.161 & ns \\
\hline Continuance Intention $\rightarrow$ Achievement Emotions & $0.853(13.282 * * *)$ & $0.829(14.864 * * *)$ & 1.029 & ns & $0.841(16.515 * * *)$ & $0.812(10.622 * * *)$ & 7.062 & $* *$ \\
\hline Continuance Intention $\rightarrow$ Challenge Emotions & $0.459(5.227 * * *)$ & $0.602(8.097 * * *)$ & 10.600 & $* *$ & $0.542\left(7.858^{* * *}\right)$ & $0.557(6.334 * * *)$ & 7.675 & $* *$ \\
\hline Continuance Intention $\rightarrow$ Loss Emotions & $-0.501(-6.430 * * *)$ & $-0.333(-6.124 * * *)$ & 1.603 & ns & $-0.421(-7.482 * * *)$ & $-0.328(-4.577 * * *)$ & 4.395 & $*$ \\
\hline Continuance Intention $\rightarrow$ Deterrence Emotions & $-0.437(-5.706 * * *)$ & $-0.299(-5.752 * * *)$ & 1.833 & ns & $-0.343(-6.201 * * *)$ & $-0.330(-4.762 * * *)$ & 6.938 & $* *$ \\
\hline
\end{tabular}

Significant at $p: n s \geq .05 ; *<.05 ; * *<.01 ; * * *<.001$ 
Table 8 Moderation analysis: demographic characteristics - age and gender

\begin{tabular}{|c|c|c|c|c|c|c|c|c|}
\hline \multirow[t]{2}{*}{ Path } & \multicolumn{4}{|c|}{ Age } & \multicolumn{4}{|c|}{ Gender } \\
\hline & $\begin{array}{l}\text { 20-39 years old } \\
\text { Coef.(t-test) }\end{array}$ & $\begin{array}{l}\geq 40 \text { years old } \\
\text { Coef.(t-test) }\end{array}$ & $\Delta \chi^{2}$ & Sig. & \begin{tabular}{|l} 
Male \\
Coef.(t-test)
\end{tabular} & \begin{tabular}{|l} 
Female \\
Coef.(t-test)
\end{tabular} & $\Delta \chi^{2}$ & Sig. \\
\hline Perceived Ease of Use $\rightarrow$ Continuance Intention & $0.619\left(6.845^{* * *}\right)$ & $0.465\left(10.175^{* * *}\right)$ & 5.745 & $*$ & $0.508\left(8.710^{* * *}\right)$ & $0.443\left(8.567^{* * *}\right)$ & 7.592 & ns \\
\hline Perceived Usefulness $\rightarrow$ Continuance Intention & $0.046(0.533 \mathrm{~ns})$ & $0.126(2.579 *)$ & 0.315 & ns & $0.152(2.561 *)$ & $0.092(1.700 \mathrm{~ns})$ & 0.041 & ns \\
\hline Perceived Ease of Use $\rightarrow$ Perceived Usefulness & $0.666(9.459 * * *)$ & $0.344\left(7.455^{* * *}\right)$ & 13.778 & $* * *$ & $0.354\left(5.692^{* * *}\right)$ & $0.425\left(8.412^{* * *}\right)$ & 0.024 & ns \\
\hline Social Inclusion $\rightarrow$ Perceived Ease of Use & $0.141(1.991 *)$ & $0.197(4.229 * * *)$ & 0.630 & ns & $0.226\left(3.906^{* * *}\right)$ & $0.150(2.904 * *)$ & 0.190 & $\mathrm{~ns}$ \\
\hline Social Inclusion $\rightarrow$ Perceived Usefulness & $0.066(1.207 \mathrm{~ns})$ & $0.061(1.514 \mathrm{~ns})$ & 0.000 & ns & $0.099(1.869 \mathrm{~ns})$ & $0.016(0.370 \mathrm{~ns})$ & 1.334 & ns \\
\hline Social Inclusion $\rightarrow$ Continuance Intention & $0.062(1.438 \mathrm{~ns})$ & $0.093(2.774 * *)$ & 0.138 & ns & $0.114(2.643 * *)$ & $0.073(2.155 *)$ & 0.766 & ns \\
\hline Need for Competence $\rightarrow$ Perceived Ease of Use & $0.240(1.437 \mathrm{~ns})$ & $0.241(2.244 *)$ & 0.003 & ns & $0.174(1.632 \mathrm{~ns})$ & $0.336(2.328 *)$ & 0.114 & $\mathrm{~ns}$ \\
\hline Need for Competence $\rightarrow$ Perceived Usefulness & $-0.120(-0.943 n s)$ & $0.468(5.047 * * *)$ & 13.575 & $* * *$ & $0.415(4.368 * * *)$ & $0.294(2.491 *)$ & 0.204 & ns \\
\hline Need for Competence $\rightarrow$ Continuance Intention & $0.115(1.155 \mathrm{~ns})$ & $0.121(1.487 \mathrm{~ns})$ & 0.011 & ns & $0.049(0.604 \mathrm{~ns})$ & $0.214\left(2.208^{*}\right)$ & 0.661 & ns \\
\hline Need for Autonomy $\rightarrow$ Perceived Ease of Use & $0.337(2.604 * *)$ & $0.195(1.889 \mathrm{~ns})$ & 0.624 & ns & $0.369(3.394 * * *)$ & $0.105(0.825 \mathrm{~ns})$ & 0.904 & ns \\
\hline Need for Autonomy $\rightarrow$ Perceived Usefulness & $-0.033(-0.325 n s)$ & $-0.129(-1.465 n s)$ & 0.582 & ns & $-0.089(-0.904 \mathrm{~ns})$ & $-0.086(-0.839 n s)$ & 0.088 & ns \\
\hline Need for Autonomy $\rightarrow$ Continuance Intention & $0.121(1.540 \mathrm{~ns})$ & $0.160(2.163 *)$ & 0.022 & ns & $0.147(1.838 \mathrm{~ns})$ & $0.128(1.550 \mathrm{~ns})$ & 4.098 & ns \\
\hline Need for Relatedness $\rightarrow$ Perceived Ease of Use & 0.138 (1.369ns) & $0.095(1.578 \mathrm{~ns})$ & 0.123 & ns & $0.058(0.873 \mathrm{~ns})$ & $0.130(1.670 \mathrm{~ns})$ & 0.270 & ns \\
\hline Need for Relatedness $\rightarrow$ Perceived Usefulness & $0.411\left(5.310^{* * *}\right)$ & $0.175\left(3.439^{* * *}\right)$ & 5.760 & $*$ & $0.176(2.977 * *)$ & $0.272(4.322 * * *)$ & 2.709 & ns \\
\hline Need for Relatedness $\rightarrow$ Continuance Intention & $0.141(1.967 *)$ & $0.178(4.092 * * *)$ & 0.007 & ns & $0.144(2.957 * *)$ & $0.191\left(3.595^{* * *}\right)$ & 0.559 & ns \\
\hline Continuance Intention $\rightarrow$ Well-being & $0.826\left(11.676^{* * *}\right)$ & $0.650\left(11.676^{* * *}\right)$ & 0.062 & ns & $0.671(10.517 * * *)$ & $0.742\left(11.993^{* * *}\right)$ & 12.112 & $* *$ \\
\hline Continuance Intention $\rightarrow$ Perceived Value & $0.858(11.615 * * *)$ & $0.882(14.010 * * *)$ & 2.717 & ns & $0.856(12.592 * * *)$ & $0.897(13.243 * * *)$ & 5.636 & $* * *$ \\
\hline Continuance Intention $\rightarrow$ Achievement Emotions & $0.894(14.261 * * *)$ & $0.832\left(16.026^{* * *}\right)$ & 1.414 & ns & $0.869(15.336 * * *)$ & $0.843(14.584 * * *)$ & 9.050 & $*$ \\
\hline Continuance Intention $\rightarrow$ Challenge Emotions & $0.701(8.744 * * *)$ & $0.615(9.471 * * *)$ & 0.573 & ns & $0.636(8.705 * * *)$ & $0.682(9.669 * * *)$ & 17.925 & $* *$ \\
\hline Continuance Intention $\rightarrow$ Loss Emotions & $-0.145(-1.901 \mathrm{~ns})$ & $-0.468(-8.084 * * *)$ & 10.516 & ** & $-0.403(-6.047 * * *)$ & $-0.279(-4.626 * * *)$ & 0.791 & ns \\
\hline Continuance Intention $\rightarrow$ Deterrence Emotions & $-0.189\left(-2.541^{*}\right)$ & $-0.343(-6.569 * * *)$ & 2.455 & ns & $-0.283(-4.432 * * *)$ & $-0.244\left(-4.255^{* * *}\right)$ & 0.116 & ns \\
\hline
\end{tabular}

Continuance Intentio

Significant at $p: n s \geq .05 ; *<.05 ; * *<.01 ; * * *<.001$ 
Table 9 Moderation analysis: Big-5 personality traits

\begin{tabular}{|c|c|c|c|c|c|c|c|c|}
\hline \multirow[t]{2}{*}{ Path } & \multicolumn{4}{|c|}{ Extroversion } & \multicolumn{4}{|c|}{ Agreeableness } \\
\hline & $\begin{array}{l}\text { Low extroversion } \\
\text { Coef.(t-test) }\end{array}$ & $\begin{array}{l}\text { High extraversion } \\
\text { Coef.(t-test) }\end{array}$ & $\Delta \chi^{2}$ & Sig. & $\begin{array}{l}\text { Low agreeableness } \\
\text { Coef.(t-test) }\end{array}$ & $\begin{array}{l}\text { High agreeableness } \\
\text { Coef.(t-test) }\end{array}$ & $\Delta \chi^{2}$ & Sig. \\
\hline Perceived Ease of Use $\rightarrow$ Continuance Intention & $0.506\left(8.651^{* * *}\right)$ & $0.500\left(9.246^{* * *}\right)$ & 0.001 & ns & $0.481(9.725 * * *)$ & $0.412\left(6.856^{* * *}\right)$ & 1.741 & ns \\
\hline Perceived Usefulness $\rightarrow$ Continuance Intention & $0.128(2.102 *)$ & $0.090(1.684 \mathrm{~ns})$ & 0.274 & ns & $0.101\left(2.000^{*}\right)$ & $0.142(2.138 *)$ & 0.021 & ns \\
\hline Perceived Ease of Use $\rightarrow$ Perceived Usefulness & $0.360\left(5.931^{* * *}\right)$ & $0.483\left(9.149^{* * *}\right)$ & 3.386 & ns & $0.439(8.579 * * *)$ & $0.309(5.141 * * *)$ & 0.835 & ns \\
\hline Social Inclusion $\rightarrow$ Perceived Ease of Use & $0.227\left(3.981^{* * *}\right)$ & $0.128(2.417 *)$ & 2.943 & ns & $0.209\left(4.365^{* * *}\right)$ & $0.080(1.221 \mathrm{~ns})$ & 4.258 & $*$ \\
\hline Social Inclusion $\rightarrow$ Perceived Usefulness & $0.054(1.035 \mathrm{~ns})$ & $0.022(0.500 \mathrm{~ns})$ & 0.289 & ns & $0.076(1.798 \mathrm{~ns})$ & $0.001(0.012 \mathrm{~ns})$ & 1.348 & ns \\
\hline Social Inclusion $\rightarrow$ Continuance Intention & $0.096(2.204 *)$ & $0.101(2.928 * *)$ & 0.057 & ns & $0.146\left(4.519^{* * *}\right)$ & $0.006(0.133 \mathrm{~ns})$ & 9.216 & $* *$ \\
\hline Need for Competence $\rightarrow$ Perceived Ease of Use & $0.166(1.383 \mathrm{~ns})$ & $0.387\left(2.880^{* *}\right)$ & 0.720 & ns & 0.249 (1.858ns) & $0.276(2.004 *)$ & 0.083 & ns \\
\hline Need for Competence $\rightarrow$ Perceived Usefulness & $0.329(3.092 * *)$ & $0.400(3.524 * * *)$ & 0.000 & ns & $0.501\left(4.245^{* * *}\right)$ & $0.215(1.901 \mathrm{~ns})$ & 4.442 & $*$ \\
\hline Need for Competence $\rightarrow$ Continuance Intention & $0.094(1.022 \mathrm{~ns})$ & $0.115(1.261 \mathrm{~ns})$ & 0.000 & ns & 0.154 (1.655ns) & 0.145 (1.464ns) & 0.254 & ns \\
\hline Need for Autonomy $\rightarrow$ Perceived Ease of Use & $0.295(2.530 *)$ & $0.131(1.115 \mathrm{~ns})$ & 1.379 & ns & $0.235(2.087 *)$ & 0.167 (1.188ns) & 0.295 & ns \\
\hline Need for Autonomy $\rightarrow$ Perceived Usefulness & $-0.059(-0.572 \mathrm{~ns})$ & $-0.124(-1.278 \mathrm{~ns})$ & 0.155 & ns & $-0.287(-2.891 * *)$ & $0.162(1.421 \mathrm{~ns})$ & 8.748 & $* *$ \\
\hline Need for Autonomy $\rightarrow$ Continuance Intention & $0.196(2.251 *)$ & $0.127(1.672 \mathrm{~ns})$ & 0.590 & ns & $0.126(1.656 \mathrm{~ns})$ & $0.157(1.575 \mathrm{~ns})$ & 0.000 & ns \\
\hline Need for Relatedness $\rightarrow$ Perceived Ease of Use & $0.121(1.776 \mathrm{~ns})$ & $0.070(0.876 \mathrm{~ns})$ & 0.308 & ns & 0.113 (1.560ns) & $0.072(0.865 \mathrm{~ns})$ & 0.363 & ns \\
\hline Need for Relatedness $\rightarrow$ Perceived Usefulness & $0.252\left(4.156^{* * *}\right)$ & $0.112(1.714 \mathrm{~ns})$ & 2.523 & ns & $0.194(3.092 * *)$ & $0.215\left(3.196^{* *}\right)$ & 0.000 & ns \\
\hline Need for Relatedness $\rightarrow$ Continuance Intention & $0.084(1.599 \mathrm{~ns})$ & $0.227(4.343 * * *)$ & 3.182 & ns & $0.157\left(3.331^{* * *}\right)$ & $0.233\left(3.808^{* * *}\right)$ & 0.009 & ns \\
\hline Continuance Intention $\rightarrow$ Well-being & $0.623(9.397 * * *)$ & $0.701\left(11.236^{* * *}\right)$ & 2.739 & ns & $0.750(13.073 * * *)$ & $0.694\left(9.526^{* * *}\right)$ & 1.988 & ns \\
\hline Continuance Intention $\rightarrow$ Perceived Value & $0.853(12.679 * * *)$ & $0.888(12.849 * * *)$ & 0.015 & ns & $0.878(13.339 * * *)$ & $0.902(11.760 * * *)$ & 14.866 & $* * *$ \\
\hline Continuance Intention $\rightarrow$ Achievement Emotions & $0.805(14.060 * * *)$ & $0.884(15.688 * * *)$ & 1.796 & ns & $0.864(15.892 * * *)$ & $0.805(11.838 * * *)$ & 1.630 & ns \\
\hline Continuance Intention $\rightarrow$ Challenge Emotions & $0.530(6.982 * * *)$ & $0.668(8.753 * * *)$ & 3.953 & $*$ & $0.695(10.908 * * *)$ & $0.675\left(8.128^{* * *}\right)$ & 2.210 & ns \\
\hline Continuance Intention $\rightarrow$ Loss Emotions & $-0.387(-5.759 * * *)$ & $-0.360(-6.009 * * *)$ & 2.993 & ns & $-0.190(-3.373 * * *)$ & $-0.456(-6.295 * * *)$ & 12.137 & $* * *$ \\
\hline Continuance Intention $\rightarrow$ Deterrence Emotions & $-0.327(-5.045 * * *)$ & $-0.302(-5.349 * * *)$ & 3.408 & ns & $-0.141(-2.609 * *)$ & $-0.329(-4.649 * * *)$ & 5.903 & $*$ \\
\hline \multirow[t]{2}{*}{ Path } & \multicolumn{4}{|c|}{ Conscientiousness } & \multicolumn{4}{|c|}{ Neuroticism } \\
\hline & $\begin{array}{l}\text { Low conscientiousness } \\
\text { Coef.(t-test) }\end{array}$ & $\begin{array}{l}\text { High conscientiousness } \\
\text { Coef.(t-test) }\end{array}$ & $\Delta \chi^{2}$ & Sig. & $\begin{array}{l}\text { Low neuroticism } \\
\text { Coef.(t-test) }\end{array}$ & $\begin{array}{l}\text { High neuroticism } \\
\text { Coef.(t-test) }\end{array}$ & $\Delta \chi^{2}$ & Sig. \\
\hline Perceived Ease of Use $\rightarrow$ Continuance Intention & $0.448(7.931 * * *)$ & $0.347(6.274 * * *)$ & 9.132 & *** & $0.470\left(7.941^{* * *}\right)$ & $0.468\left(9.255^{* * *}\right)$ & 1.278 & ns \\
\hline Perceived Usefulness $\rightarrow$ Continuance Intention & $0.174\left(3.115^{* *}\right)$ & $0.122(1.967 *)$ & 3.406 & ns & $0.113(1.791 \mathrm{~ns})$ & $0.121\left(2.356^{*}\right)$ & 0.399 & ns \\
\hline Perceived Ease of Use $\rightarrow$ Perceived Usefulness & $0.489(8.529 * * *)$ & $0.357\left(6.771^{* * *}\right)$ & 0.108 & ns & $0.395(6.637 * * *)$ & $0.395(7.591 * * *)$ & 0.741 & ns \\
\hline Social Inclusion $\rightarrow$ Perceived Ease of Use & $0.113\left(2.315^{*}\right)$ & $0.130\left(2.161^{*}\right)$ & 0.000 & ns & $0.159(2.671 * *)$ & $0.128(2.527 *)$ & 0.023 & ns \\
\hline Social Inclusion $\rightarrow$ Perceived Usefulness & $0.039(0.910 \mathrm{~ns})$ & $0.063(1.314 \mathrm{~ns})$ & 0.315 & ns & 0.054 (1.083ns) & $0.042(0.971 \mathrm{~ns})$ & 0.045 & ns \\
\hline Social Inclusion $\rightarrow$ Continuance Intention & $0.083(2.537 *)$ & $0.092(2.183 *)$ & 0.423 & ns & $0.140(3.454 * * *)$ & $0.062(1.768 \mathrm{~ns})$ & 0.742 & ns \\
\hline Need for Competence $\rightarrow$ Perceived Ease of Use & 0.185 (1.646ns) & $0.311(2.118 *)$ & 0.097 & ns & $0.292(1.757 \mathrm{~ns})$ & $0.223(2.074 *)$ & 0.002 & ns \\
\hline Need for Competence $\rightarrow$ Perceived Usefulness & $0.311(3.202 * *)$ & $0.384\left(3.261^{* *}\right)$ & 0.460 & ns & $0.532(3.788 * * *)$ & $0.247\left(2.698^{* *}\right)$ & 2.453 & ns \\
\hline Need for Competence $\rightarrow$ Continuance Intention & $0.049(0.640 \mathrm{~ns})$ & $0.238(2.212 *)$ & 0.598 & ns & 0.204 (1.715ns) & $0.102(1.361 \mathrm{~ns})$ & 0.079 & ns \\
\hline
\end{tabular}




\begin{tabular}{|c|c|c|c|c|}
\hline Need for Autonomy $\rightarrow$ Perceived Ease of Use & $0.340(3.044 * *)$ & $0.059(0.466 \mathrm{~ns})$ & 3.641 & ns \\
\hline Need for Autonomy $\rightarrow$ Perceived Usefulness & $-0.100(-1.016 \mathrm{~ns})$ & $-0.087(-0.859 \mathrm{~ns})$ & 0.000 & ns \\
\hline Need for Autonomy $\rightarrow$ Continuance Intention & $0.202(2.637 * *)$ & $0.093(1.051 \mathrm{~ns})$ & 2.736 & ns \\
\hline Need for Relatedness $\rightarrow$ Perceived Ease of Use & $0.196(2.948 * *)$ & $0.095(1.130 \mathrm{~ns})$ & 2.024 & ns \\
\hline Need for Relatedness $\rightarrow$ Perceived Usefulness & $0.202(3.468 * * *)$ & $0.224(3.352 * * *)$ & 0.114 & ns \\
\hline Need for Relatedness $\rightarrow$ Continuance Intention & $0.157(3.391 * * *)$ & $0.276(4.444 * * *)$ & 0.157 & ns \\
\hline Continuance Intention $\rightarrow$ Well-being & $0.812(13.351 * * *)$ & $0.738\left(10.456^{* * *}\right)$ & 30.243 & $* * *$ \\
\hline Continuance Intention $\rightarrow$ Perceived Value & $0.875(13.140 * * *)$ & $0.880(11.000 * * *)$ & 26.815 & **** \\
\hline Continuance Intention $\rightarrow$ Achievement Emotions & $0.869(15.522 * * *)$ & $0.802(11.472 * * *)$ & 8.890 & $* *$ \\
\hline Continuance Intention $\rightarrow$ Challenge Emotions & $0.722(11.114 * * *)$ & $0.729(9.134 * * *)$ & 20.409 & $* * *$ \\
\hline Continuance Intention $\rightarrow$ Loss Emotions & $-0.135(-2.236 *)$ & $-0.451(-6.501 * * *)$ & 23.167 & $* * *$ \\
\hline Continuance Intention $\rightarrow$ Deterrence Emotions & $-0.081(-1.401 \mathrm{~ns})$ & $-0.318(-4.775 * * *)$ & 10.999 & *** \\
\hline Path & \multicolumn{4}{|c|}{ Imagination } \\
\hline & \begin{tabular}{|l|} 
Low imagination \\
Coef.(t-test)
\end{tabular} & $\begin{array}{l}\text { High imagination } \\
\text { Coef.(t-test) }\end{array}$ & $\Delta \chi^{2}$ & Sig. \\
\hline Perceived Ease of Use $\rightarrow$ Continuance Intention & $0.438(9.151 * * *)$ & $0.522(7.817 * * *)$ & 1.967 & ns \\
\hline Perceived Usefulness $\rightarrow$ Continuance Intention & $0.133(2.768 * *)$ & $0.047(0.679 \mathrm{~ns})$ & 1.323 & ns \\
\hline Perceived Ease of Use $\rightarrow$ Perceived Usefulness & $0.428(8.740 * * *)$ & $0.314\left(4.665^{* * *}\right)$ & 0.229 & ns \\
\hline Social Inclusion $\rightarrow$ Perceived Ease of Use & $0.214(4.608 * * *)$ & $0.121(1.811 \mathrm{~ns})$ & 3.782 & ns \\
\hline Social Inclusion $\rightarrow$ Perceived Usefulness & $0.054(1.331 \mathrm{~ns})$ & $-0.001(-0.023 n s)$ & 0.774 & ns \\
\hline Social Inclusion $\rightarrow$ Continuance Intention & $0.106\left(3.270^{* *}\right)$ & $0.072(1.576 \mathrm{~ns})$ & 1.121 & ns \\
\hline Need for Competence $\rightarrow$ Perceived Ease of Use & $0.266(2.398 *)$ & $0.100(0.618 \mathrm{~ns})$ & 1.426 & ns \\
\hline Need for Competence $\rightarrow$ Perceived Usefulness & $0.299(3.125 * *)$ & $0.469\left(3.530^{* * *}\right)$ & 0.591 & ns \\
\hline Need for Competence $\rightarrow$ Continuance Intention & $0.077(1.004 \mathrm{~ns})$ & $0.285(2.446 *)$ & 1.538 & ns \\
\hline Need for Autonomy $\rightarrow$ Perceived Ease of Use & $0.119(1.173 \mathrm{~ns})$ & $0.446(2.877 * *)$ & 2.512 & ns \\
\hline Need for Autonomy $\rightarrow$ Perceived Usefulness & $-0.038(-0.441 \mathrm{~ns})$ & $-0.186(-1.415 n s)$ & 0.915 & ns \\
\hline Need for Autonomy $\rightarrow$ Continuance Intention & $0.209\left(3.045^{* *}\right)$ & $-0.015(-0.134 n s)$ & 3.343 & ns \\
\hline Need for Relatedness $\rightarrow$ Perceived Ease of Use & $0.204(3.223 * *)$ & $0.014(0.158 \mathrm{~ns})$ & 4.623 & $*$ \\
\hline Need for Relatedness $\rightarrow$ Perceived Usefulness & $0.183\left(3.353^{* * *}\right)$ & $0.295(3.915 * * *)$ & 0.652 & ns \\
\hline Need for Relatedness $\rightarrow$ Continuance Intention & $0.193\left(4.358^{* * *}\right)$ & $0.236(3.572 * * *)$ & 0.044 & ns \\
\hline Continuance Intention $\rightarrow$ Well-being & $0.764(13.252 * * *)$ & $0.663\left(8.616^{* * *}\right)$ & 0.073 & ns \\
\hline Continuance Intention $\rightarrow$ Perceived Value & $0.891(13.557 * * *)$ & $0.829\left(10.466^{* * *}\right)$ & 0.262 & ns \\
\hline Continuance Intention $\rightarrow$ Achievement Emotions & $0.840(15.479 * * *)$ & $0.847(12.189 * * *)$ & 1.376 & ns \\
\hline Continuance Intention $\rightarrow$ Challenge Emotions & $0.671(10.410 * * *)$ & $0.671(7.868 * * *)$ & 0.450 & ns \\
\hline Continuance Intention $\rightarrow$ Loss Emotions & $-0.182(-3.293 * * *)$ & $-0.484(-6.024 * * *)$ & 9.661 & $* *$ \\
\hline Continuance Intention $\rightarrow$ Deterrence Emotions & $-0.113(-2.122 *)$ & $-0.371(-5.121 * * *)$ & 8.496 & ** \\
\hline
\end{tabular}

\begin{tabular}{||l|l|l|l|}
$0.146(0.965 \mathrm{~ns})$ & $0.334\left(3.386^{* * *}\right)$ & 1.628 & $\mathrm{~ns}$ \\
\hline$-0.124(-0.989 \mathrm{~ns})$ & $-0.107(-1.255 \mathrm{~ns})$ & 0.016 & $\mathrm{~ns}$ \\
\hline $0.071(0.706 \mathrm{~ns})$ & $0.205(2.944 * *)$ & 2.425 & $\mathrm{~ns}$ \\
\hline $0.154(1.832 \mathrm{~ns})$ & $0.086(1.311 \mathrm{~ns})$ & 0.228 & $\mathrm{~ns}$ \\
\hline $0.063(0.894 \mathrm{~ns})$ & $0.353(6.244 * * *)$ & 9.897 & $* *$ \\
\hline $0.185\left(3.286^{* *}\right)$ & $0.149(3.064 * *)$ & 0.080 & $\mathrm{~ns}$ \\
\hline $0.725\left(10.293^{* * *}\right)$ & $0.733\left(12.689^{* * *}\right)$ & 9.193 & $* *$ \\
\hline $0.920\left(11.963^{* * *}\right)$ & $0.859(13.544 * * *)$ & 15.063 & $* * *$ \\
\hline $0.859\left(12.985^{* * *}\right)$ & $0.855\left(16.389^{* * *}\right)$ & 2.489 & $\mathrm{~ns}$ \\
\hline $0.641\left(7.914^{* * *)}\right.$ & $0.697\left(10.826^{* * *}\right)$ & 0.508 & $\mathrm{~ns}$ \\
\hline$-0.534\left(-7.130^{* * *}\right)$ & $-0.203\left(-3.529^{* * *}\right)$ & 17.115 & $* * *$ \\
\hline$-0.443\left(-6.460^{* * *}\right)$ & $-0.140\left(-2.545^{*}\right)$ & 12.397 & $* * *$ \\
\hline
\end{tabular}

$-0.140\left(-2.545^{*}\right)$

12.397

Intention $\rightarrow$ Deterrence Emotion

Significant at $p: n s \geq .05 ; *<.05 ; * *<.01 ; * * *<.001$ 


\section{Discussion}

\subsection{Technology acceptance}

This study has extended TAM using a number of psychological antecedents and outcomes, following the causal chain of IS theories (Bagozzi et al., 1992; Davis et al., 1989; Venkatesh et al., 2003; Taylor \& Todd, 1995). As the majority of the hypotheses (H1-H8) were accepted, this study further corroborated the robustness, flexibility for extensions, and explanatory power of TAM (Mathieson, 1991; Venkatesh et al., 2003; Davis, 1989). Path analysis results suggested that Perceived Ease of Use had a stronger relationship to Continuance Intentions than Perceived Usefulness. This research did not support previous literature which suggested that Perceived Ease of Use is less influential than Perceived Usefulness when it comes to technology acceptance (e.g. Chau, 1996; Davis et al., 1989). One possible interpretation may be that the users' increasing familiarity with the Internet may alter their expectations on new ICTs (Mathieson, 1991). Perceived Usefulness was significantly and strongly influenced by Perceived Ease of Use, and this relationship was greater for high Internet use behaviour and expertise groups. These findings supported the ideas that the role of Perceived Ease of Use may switch from forming intentions to mainly influencing Perceived Usefulness in a later stage of technology adoption (Venkatesh \& Bala, 2008). In the cases of accepting new technology, user background knowledge has been found to positively relate to their Perceived Usefulness (Kardooni, Yusoff, \& Kari, 2016), whereas insufficient subjective knowledge could be a barrier (Liu et al., 2018). The relationships of Perceived Ease of Use with Perceived Usefulness and Continuance Intention were weaker for high-age users. This is in contrast to previous literature reporting that Perceived Ease of Use was more influential among older users (Venkatesh \& Morris, 2000; Venkatesh et al., 2003). This may be explained by the fact that Internet users falling into such groups may have 15-20 years of experience with the technology and services, compared to those surveyed in the past.

\subsection{Social inclusion and satisfaction of needs}

This paper has provided evidence for the relationship between social inclusion and technology acceptance (i.e. PEOU and CI), which is broadly consistent with previous findings (Choi \& Chung, 2013; Park, 2010; Park et al., 2013; Smith \& Sivo, 2012). Our statistical results suggested that social inclusion had a weaker relationship with continuance intention of the Internet among the proficient users, which is in line with the viewpoint of Venkatesh and Davis (2000) and Venkatesh et al. (2003). For the less experienced users, being socially included could strengthen their beliefs in the easiness of using the Internet and drive their intention to continue using it. This finding also corroborates the standpoint that new forms of technological breakthrough possibly create new forms of digital/social exclusion (Andrade \& Doolin, 2016; Hill et al., 2015; Selwyn, 2002). Lack of digital knowledge and skills consequently causes people to be excluded from participating in society or networks of information (Andrade \& Doolin, 2016; Hill et al., 2015).

Two of the main relationships between psychological need satisfaction and TAM were not supported, namely the relationship between Need for Competence and Continuance Intention and between Need for Autonomy and Perceived Usefulness. The overall effects of the Need for Competence on TAM were in line with previous results (Huang et al., 2016; Lee et al., 2015; Roca \& Gagné, 2008). The relationship between the need for Autonomy and Perceived Ease of Use and Continuance Intention partially supported previous findings (Hew \& Kadir, 2016; Huang et al., 2016; Nikou \& Economides, 2017; Roca \& Gagné, 2008). Statistical results reported significant relationships between the Need for Relatedness and TAM, which were broadly consistent with Huang et al. (2016), Lee et al. (2015) and Nikou and Economides (2017). The relationship between the needs for Autonomy and Relatedness on one's Continuance Intention were significant, which partially corroborated the viewpoint that the psychological need fulfilment perceived online enhances Internet use (Shen et al., 2013). Moderation tests suggested that the relationship between the Need for Competence and Perceived Usefulness was stronger for less experienced users. The relationship between the 
Need for Autonomy and Perceived Usefulness was only significant among the less Internetknowledgeable individuals. These findings suggested that the determining role of psychological needs satisfied by technology use would be attenuated with increased experience (Venkatesh \& Bala, 2008; Gagné \& Deci, 2005; Ryan \& Deci, 2000b). Additionally, the increase of age strengthened the effects of the Need for Competence, but dampened the relationship between the Need for Relatedness and Perceived Usefulness. Fulfilling the Need for Relatedness enhances young people's belief in the usefulness of the Internet, whereas satisfying the Need for Competence boosts the older or novice users' acceptance.

\subsection{Intention and psychological outcomes}

This paper has investigated six psychological outcomes of using the Internet. Path coefficients indicated that the intention to continue using the Internet positively affected the positive outcomes, i.e. well-being, perceived value, and positive emotions (related to how participants felt after using the Internet). The negative coefficients between intention and negative emotions offered additional evidence that the outcome of using the Internet is, overall, beneficial. The results presented a strong relationship between Continuance Intention and Well-being (Rahman et al., 2017; Munzel et al., 2017; Partala \& Saari, 2015). This finding could be partially attributed to the viewpoint that using the Internet can strengthen the effect of Social Inclusion on Well-being (Andrade \& Doolin, 2016). The correlation between the Continuance Intention of Internet use and Perceived Value was significant and strong, which confirmed the finding of Kim et al. (2008) and Partala and Saari (2015).

This study categorised users' emotional reactions after using the internet into four dimensions according to Beaudry and Pinsonneault, (2010). The two positive emotions, i.e. achievement and challenge, were strongly affected by continuance intention. The negative emotions, i.e. loss and deterrence, had comparatively weaker relationships with the users' intention. These findings agreed with previous studies suggesting that users could experience both positive and negative emotions triggered by the same technology (Beaudry \& Pinsonneault, 2010; Chang et al., 2014; Partala \& Saari, 2015; Partala \& Kujala, 2015).

The moderation test results provided strong evidence for the significance of the Big-5 personality traits when using the Internet (Desmet \& Hekkert, 2007; Munzel et al., 2017). The Internet caused stronger negative emotions among the more agreeable, conscientious, imaginative, or less neurotic users, though the Internet may possess value for them. Also, neurotic or less conscientious users experienced a higher level of well-being. These findings could possibly be attributed to the emotional value of the Internet. Using the Internet may help neurotic people achieve a higher level of well-being and reduce negative emotions. The more agreeable, conscientious, or imaginative Internet users may seek excitement and playfulness rather than emotional relief.

The moderating effects on the two categories of positive emotions were in opposite directions. For the proficient, female, or more conscientious users, the Internet was more likely to arouse challenge emotions, but less likely to evoke achievement emotions. This could be because using a new IS/IT evokes positive emotions when the users regard it as an effective approach to achieving their goals or tasks (Beaudry \& Pinsonneault, 2010). In this case, the new technology would arouse achievement emotions for users who are able to achieve the expected outcomes or evoke challenge emotions for those who have full control over the benefits (Lee et al., 2012; Beaudry \& Pinsonneault, 2010). Therefore, proficient or more conscientious individuals who perceived themselves as having more control over their use of Internet technologies experienced more challenge emotions (Beaudry \& Pinsonneault, 2005; Beaudry \& Pinsonneault, 2010).

\section{Conclusions, contributions, and implications}

A gap has been identified in the literature when it comes exploring the emotional 
influence that a pervasive technological paradigm can bring to the public. Also, incorporating individual characteristics, e.g. psychological states and emotional responses, had been suggested as an approach to enhance technology acceptance theories. This article has contributed to existing knowledge of IS studies by tackling these two objectives. A model incorporating many psychological constructs has been theorised and empirically validated. A number of personal attributes were also tested as moderators with the aim of providing insights into the potential moderation effects on the E-TAM.

This article made a second main contribution in terms of facilitating the understanding of how psychological and social factors enhance users' beliefs toward ICTs. Specifically, being socially included can encourage the novices to accept new ICTs, which may alleviate the potential digital exclusion brought about by the diffusion of novel technological breakthroughs (Andrade \& Doolin, 2016; Hill et al., 2015; Tapia et al., 2011). Social inclusion was especially important in determining the perceived ease of use and continuance intention for the less-experienced individuals. The moderation effects also suggested that psychological need satisfaction has a stronger relationship with perceived usefulness for the younger or experienced users. For the less-experienced users, using the Internet was less likely to enhance well-being or evoke positive challenge emotions. They also suffered more from the negative emotions. Taken together, these findings suggested that the novice users believe that the use of the Internet constitutes threats (Beaudry \& Pinsonneault, 2010), but using the Internet is an effective approach to gaining competence and autonomy. Still, the perceived limitations on IS/IT knowledge and experience is a barrier which hinders them from benefitting from technology acceptance and use (Kardooni et al., 2016; Liu et al., 2018). Social support can mitigate the negative effect of users' emotional barriers toward using a new IS/IT (Venkatesh et al., 2003; Beaudry \& Pinsonneault, 2010). Therefore, being socially included could encourage the less-experienced users to accept and use new technologies, which further enhances the benefits of technology implementation.

The third contribution emerged from the findings on the emotional outcomes and moderation effects. Our findings implied that the degree of emotional reactions may vary depending on personal traits. The Internet is more likely to arouse challenge emotions but less likely to evoke achievement emotions among users with a higher degree of Internet expertise, those who are highly conscientious, or who are female. What is more, gaining competitiveness and avoiding social/digital exclusion can only motivate new IS/IT acceptance for the novice, as discussed above. The Internet may help Internet-knowledgeable or neurotic users to achieve a higher level of well-being and reduce negative emotions. Users with higher degrees of agreeableness, conscientiousness, and imagination may use the Internet to seek excitements or playfulness.

\section{Limitations and future research avenues}

This article is not without limitations. This paper posited direct effects between psychological factors and TAM-based constructs. Further tests and validations such as the interactions and crossover effects between these emotional variables are required. Similarly, the multi-group approach of moderating effects test did not evaluate the interactions between moderators. In addition, the data was collected from consumers in the U.S. to elaborate the influential emotional states and consequences of using the Internet. In addition, it may be worth considering measuring emotional responses over a period of time (e.g. in a diary format), which may offer more granular insights into user responses when it comes to using the Internet. The compatibility of the E-TAM framework should be examined in other contexts, such as users in societies with different social/cultural backgrounds. Finally, future studies could, beyond confirming and validating this study's findings when it comes to elaborating how the big changes in technological paradigms (e.g. moving from web 1.0 to web 2.0 and then web 3.0) transform individuals' emotional states. 
References

ANDERSSON, G. 2009. Using the Internet to provide cognitive behaviour therapy. Behaviour Research and Therapy, 47 (3), 175-180.

ANDRADE, A. D. \& DOOLIN, B. 2016. Information and communication technology and the social inclusion of refugees. Mis Quarterly, 40 (2), 405-416.

BAGOZZI, R. P. 1992. The self-regulation of attitudes, intentions, and behavior. Social Psychology Quarterly, 178-204.

BAGOZZI, R. P. 2007. The legacy of the Technology Acceptance Model and a proposal for a paradigm shift. Journal of the Association for Information Systems, 8 (4), 3.

BAGOZZI, R. P., DAVIS, F. D. D. \& WARSHAW, P. R. 1992. Development and test of a theory of technological learning and usage. Human Relations, 45 (7), 659-686.

BARRICK, M. R. \& MOUNT, M. K. 1991. The big five personality dimensions and job performance: A meta- analysis. Personnel Psychology, 44 (1), 1-26.

BEAUDRY, A. \& PINSONNEAULT, A. 2005. Understanding user responses to information technology: A coping model of user adaptation. MIS Quarterly, 493-524.

BEAUDRY, A. \& PINSONNEAULT, A. 2010. The other side of acceptance: Studying the direct and indirect effects of emotions on information technology use. MIS Quarterly, 34 (4), 689-710.

BENBASAT, I. \& BARKI, H. 2007. Quo vadis TAM? Journal of the Association for Information Systems, 8 (4), 7.

BROADBENT, R. \& PAPADOPOULOS, T. 2013. Impact and benefits of digital inclusion for social housing residents. Community Development, 44 (1), 55-67.

BURCHARDT, T., LE GRAND, J. \& PIACHAUD, D. 1999. Social Exclusion in Britain 1991-1995. Social Policy and Administration, 33 (3), 227-244.

CASALE, S. \& FIORAVANTI, G. 2015. Satisfying needs through Social Networking Sites: A pathway towards problematic Internet use for socially anxious people? Addictive Behaviors Reports, 1, 34-39.

CASTAñEDA, J. A., MUñOZ-LeIVA, F. \& LUQUE, T. 2007. Web Acceptance Model (WAM): Moderating effects of user experience. Information \& Management, 44 (4), 384-396.

CHANG, Y., DONG, X. \& SUN, W. 2014. Influence of characteristics of the Internet of Things on consumer purchase intention. Social Behavior and Personality, 42 (2), 321-330.

CHAU, P. Y. K. 1996. An empirical assessment of a modified Technology Acceptance Model. Journal of Management Information Systems, 13 (2), 185-204.

CHOI, G. \& CHUNG, H. 2013. Applying the Technology Acceptance Model to Social Networking Sites (SNS): Impact of subjective norm and social capital on the acceptance of SNS. International Journal of Human-Computer Interaction, 29 (10), 619-628.

CHONG, A. Y. L., LIU, M. J., LUO, J. \& KENG-BOON, O. 2015. Predicting RFID adoption in healthcare supply chain from the perspectives of users. International Journal of Production Economics, 159, 66-75.

COSTA, P. T. \& MACCRAE, R. R. 1992. Revised NEO personality inventory (NEO PI-R) and NEO five-factor inventory (NEO-FFI): Professional manual, Psychological Assessment Resources, Incorporated. 
CREDé, M., HARMS, P., NIEHORSTER, S. \& GAYE-VALENTINE, A. 2012. An evaluation of the consequences of using short measures of the Big Five personality traits. Journal of Personality and Social Psychology, 102 (4), 874.

DAVIS, F. D. 1989. Perceived usefulness, perceived ease of use, and user acceptance of information technology. MIS Quarterly, 319-340.

DAVIS, F. D., BAGOZZI, R. P. \& WARSHAW, P. R. 1989. User acceptance of computer technology: A comparison of two theoretical models. Management Science, 35 (8), 982-1003.

DAVIS, F. D., BAGOZZI, R. P. \& WARSHAW, P. R. 1992. Extrinsic and intrinsic motivation to use computers in the workplace. Journal of Applied Social Psychology, 22 (14), 1111-1132.

DAVIS, F. D. \& VENKATESH, V. 2004. Toward preprototype user acceptance testing of new information systems: Implications for software project management. IEEE Transactions on Engineering Management, 51 (1), 31-46.

DAVIS, R. A. 2001. A cognitive-behavioral model of pathological Internet use. Computers in Human Behavior, 17 (2), 187-195.

DECI, E. L. \& RYAN, R. M. 2000. The" what" and" why" of goal pursuits: Human needs and the self-determination of behavior. Psychological Inquiry, 11 (4), 227-268.

DENNIS, C., ALAMANOS, E., PAPAGIANNIDIS, S. \& BOURLAKIS, M. 2016. Does social exclusion influence multiple channel use? The interconnections with community, happiness, and well-being. Journal of Business Research, 69 (3), 10611070.

DESMET, P. \& HEKKERT, P. 2007. Framework of product experience. International Journal of Design, 1 (1), 57-66.

DEVARAJ, S., EASLEY, R. F. \& CRANT, J. M. 2008. How does personality matter? Relating the five-factor model to technology acceptance and use. Information Systems Research, 19 (1), 93-105.

DISHAW, M. T. \& STRONG, D. M. 1999. Extending the Technology Acceptance Model with task-technology fit constructs. Information and Management, 36 (1), 9-21.

DONNELLAN, M. B., OSWALD, F. L., BAIRD, B. M. \& LUCAS, R. E. 2006. The miniIPIP scales: Tiny-yet-effective measures of the Big Five factors of personality. Psychological Assessment, 18 (2), 192.

EL HEDHLI, K., CHEBAT, J.-C. \& SIRGY, M. J. 2013. Shopping well-being at the mall: Construct, antecedents, and consequences. Journal of Business Research, 66 (7), 856863.

GAGNé, M. \& DECI, E. L. 2005. Self- determination theory and work motivation. Journal of Organizational Behavior, 26 (4), 331-362.

GASKIN, J. 2016. Excel StatTools, Stats Tools Package. Available at: http://statwiki.kolobkreations.com.

GEFEN, D. \& RIDINGS, C. M. 2005. If you spoke as she does, sir, instead of the way you do: A sociolinguistics perspective of gender differences in virtual communities. The DATA BASE for Advances in Information Systems, 36 (2), 78-92.

HAIR JR, J. F., BLACK, W. C., BABIN, B. J. \& ANDERSON, R. E. 2014. Multivariate data analysis, London, UK, Pearson Education Limited.

HAUSMAN, A. V. \& SIEKPE, J. S. 2009. The effect of web interface features on consumer online purchase intentions. Journal of Business Research, 62 (1), 5-13. 
HEW, T.-S. \& KADIR, S. L. S. A. 2016. Predicting the acceptance of cloud-based virtual learning environment: The roles of Self Determination and Channel Expansion Theory. Telematics and Informatics, 33 (4), 990-1013.

HILL, R., BETTS, L. R. \& GARDNER, S. E. 2015. Older adults' experiences and perceptions of digital technology: (Dis)empowerment, wellbeing, and inclusion. Computers in Human Behavior, 48, 415-423.

HUANG, Y. C., BACKMAN, K. F., BACKMAN, S. J. \& CHANG, L. L. 2016. Exploring the implications of virtual reality technology in tourism marketing: An integrated research framework. International Journal of Tourism Research, 18 (2), 116-128.

HUXLEY, P., EVANS, S., MADGE, S., WEBBER, M., BURCHARDT, T., MCDAID, D. \& KNAPP, M. 2012. Development of a social inclusion index to capture subjective and objective life domains (phase II): Psychometric development study. Health Technology Assessment, 16 (1), 1-248.

HWANG, Y. 2010. The moderating effects of gender on e-commerce systems adoption factors: An empirical investigation. Computers in Human Behavior, 26 (6), 17531760.

KARDOONI, R., YUSOFF, S. B. \& KARI, F. B. 2016. Renewable energy technology acceptance in Peninsular Malaysia. Energy Policy, 88, 1-10.

KENNAN, M. A., LLOYD, A., QAYYUM, A. \& THOMPSON, K. 2011. Settling in: The relationship between information and social inclusion. Australian Academic \& Research Libraries, 42 (3), 191-210.

KIM, J., LAROSE, R. \& PENG, W. 2009. Loneliness as the cause and the effect of problematic Internet use: The relationship between Internet use and psychological well-being. CyberPsychology \& Behavior, 12 (4), 451-455.

KIM, J. \& LENNON, S. J. 2013. Effects of reputation and website quality on online consumers' emotion, perceived risk and purchase intention: Based on the StimulusOrganism-Response Model. Journal of Research in Interactive, 7 (1), 33-56.

KIM, S. H. 2008. Moderating effects of job relevance and experience on mobile wireless technology acceptance: Adoption of a smartphone by individuals. Information \& Management, 45 (6), 387-393.

KIM, T. G., LEE, J. H. \& LAW, R. 2008. An empirical examination of the acceptance behaviour of hotel front office systems: An extended Technology Acceptance Model. Tourism Management, 29 (3), 500-513.

LAROSE, R. 2010. The problem of media habits. Communication Theory, 20 (2), 194-222.

LAZARUS, R. S. \& FOLKMAN, S. 1984. Coping and adaptation. The Handbook of Behavioral Medicine, 282-325.

LEE, W., XIONG, L. \& HU, C. 2012. The effect of Facebook users' arousal and valence on intention to go to the festival: Applying an extension of the technology acceptance model. International Journal of Hospitality Management, 31 (3), 819-827.

LEE, Y., KOZAR, K. A. \& LARSEN, K. R. 2003. The technology acceptance model: Past, present, and future. Communications of the Association for information systems, 12 (1), 50 .

LEE, Y., LEE, J. \& HWANG, Y. 2015. Relating motivation to information and communication technology acceptance: Self-determination theory perspective. Computers in Human Behavior, 51, 418-428.

LIU, Y., HONG, Z., ZHU, J., YAN, J., QI, J. \& LIU, P. 2018. Promoting green residential buildings: Residents' environmental attitude, subjective knowledge, and social trust 
matter. Energy Policy, 112, 152-161.

LOWRY, P. B., GASKIN, J., TWYMAN, N., HAMMER, B. \& ROBERTS, T. 2013. Taking 'fun and games' seriously: Proposing the Hedonic-Motivation System Adoption Model (HMSAM). Journal of the Association for Information Systems, 14 (11), 617671.

MATHIESON, K. 1991. Predicting user intentions: Comparing the technology acceptance model with the Theory of Planned Behavior. Information Systems Research, 2 (3), 173-191.

MATHWICK, C. \& RIGDON, E. 2004. Play, flow, and the online search experience. Journal of Consumer Research, 31 (2), 324-332.

MOHD SUKI, N., RAMAYAH, T. \& MOHD SUKI, N. 2008. Internet shopping acceptance: Examining the influence of intrinsic versus extrinsic motivations. Direct Marketing: An International Journal, 2 (2), 97-110.

MORRIS, M. G. \& VENKATESH, V. 2000. Age differences in technology adoption decisions: Implications for a changing work force. Personnel Psychology, 53 (2), 375-403.

MUNNO, D., CAPPELlin, F., SAROLDI, M., BECHON, E., GUGLIELMUCCI, F., PASSERA, R. \& ZULLO, G. 2017. Internet addiction disorder: Personality characteristics and risk of pathological overuse in adolescents. Psychiatry Research, $248,1-5$.

MUNZEL, A., MEYER-WAARDEN, L. \& GALAN, J.-P. 2017. The social side of sustainability: Well-being as a driver and an outcome of social relationships and interactions on social networking sites. Technological Forecasting and Social Change.

NIEMZ, K., GRIFFITHS, M. \& BANYARD, P. 2005. Prevalence of pathological Internet use among university students and correlations with self-esteem, the General Health Questionnaire (GHQ), and disinhibition. CyberPsychology \& Behavior, 8 (6), 562570.

NIKOU, S. A. \& ECONOMIDES, A. A. 2017. Mobile-Based Assessment: Integrating acceptance and motivational factors into a combined model of Self-Determination Theory and Technology Acceptance. Computers in Human Behavior, 68, 83-95.

NISTOR, N. 2014. When technology acceptance models won't work: Non-significant intention-behavior effects. Computers in Human Behavior, 34, 299-300.

OKADA, E. M. 2005. Justification effects on consumer choice of hedonic and utilitarian goods. Journal of Marketing Research, 42 (1), 43-53.

OLIVER, R. L. \& BEARDEN, W. O. 1985. Crossover effects in the theory of reasoned action: A moderating influence attempt. Journal of Consumer Research, 12 (3), 324-340.

ÖZBEK, V., ALNıAçıK, Ü., KOC, F., AKKıLıç, M. E. \& KAŞ, E. 2014. The impact of personality on technology acceptance: A study on smart phone users. Procedia-Social and Behavioral Sciences, 150, 541-551.

PARK, N. 2010. Adoption and use of computer- based voice over Internet protocol phone service: Toward an integrated model. Journal of Communication, 60 (1), 40-72.

PARK, N., KIM, Y.-C., SHON, H. Y. \& SHIM, H. 2013. Factors influencing smartphone use and dependency in South Korea. Computers in Human Behavior, 29 (4), 1763-1770.

PARTALA, T. 2011. Psychological needs and virtual worlds: Case Second Life. International Journal of Human-Computer Studies, 69 (12), 787-800.

PARTALA, T. \& KUJALA, S. 2015. Exploring the role of ten universal values in using 
products and services. Interacting with Computers, 28 (3), 311-331.

PARTALA, T. \& SAARI, T. 2015. Understanding the most influential user experiences in successful and unsuccessful technology adoptions. Computers in Human Behavior, $53,381-395$.

RAHMAN, S. A., TAGHIZADEH, S. K., RAMAYAH, T. \& ALAM, M. M. D. 2017. Technology acceptance among micro-entrepreneurs in marginalized social strata: The case of social innovation in Bangladesh. Technological Forecasting and Social Change, 118, 236-245.

RICHARDSON, L. \& LE GRAND, J. 2002. Outsider and insider expertise: The response of residents of deprived neighbourhoods to an academic definition of social exclusion. Social Policy \& Administration, 36 (5), 496-515.

ROCA, J. C. \& GAGNé, M. 2008. Understanding e-learning continuance intention in the workplace: A self-determination theory perspective. Computers in Human Behavior, 24 (4), 1585-1604.

RUSSELL, J. A. \& CARROLL, J. M. 1999. On the bipolarity of positive and negative affect. Psychological Bulletin, 125 (1), 3.

RYAN, R. M. \& DECI, E. L. 2000a. The darker and brighter sides of human existence: Basic psychological needs as a unifying concept. Psychological Inquiry, 11 (4), 319-338.

RYAN, R. M. \& DECI, E. L. 2000b. Intrinsic and extrinsic motivations: Classic definitions and new directions. Contemporary Educational Psychology, 25 (1), 54-67.

RYAN, R. M. \& DECI, E. L. 2000c. Self-determination theory and the facilitation of intrinsic motivation, social development, and well-being. American Psychologist, 55 (1), 6878.

SAYCE, L. 2001. Social inclusion and mental health. Psychiatric Bulletin, 25 (4), 121-123.

SECKER, J., HACKING, S., KENT, L., SHENTON, J. \& SPANDLER, H. 2009. Development of a measure of social inclusion for arts and mental health project participants. Journal of Mental Health, 18 (1), 65-72.

SELWYN, N. 2002. 'E-stablishing' an inclusive society? Technology, social exclusion and UK government policy making. Journal of Social Policy, 31 (1), 1-20.

SHEN, C.-X., LIU, R.-D. \& WANG, D. 2013. Why are children attracted to the Internet? The role of need satisfaction perceived online and perceived in daily real life. Computers in Human Behavior, 29 (1), 185-192.

SMITH, J. A. \& SIVO, S. A. 2012. Predicting continued use of online teacher professional development and the influence of social presence and sociability. British Journal of Educational Technology, 43 (6), 871-882.

SøREB $\emptyset, \emptyset .$, HALVARI, H., GULLI, V. F. \& KRISTIANSEN, R. 2009. The role of selfdetermination theory in explaining teachers' motivation to continue to use e-learning technology. Computers \& Education, 53 (4), 1177-1187.

SVENDSEN, G. B., JOHNSEN, J.-A. K., ALMåS-SøRENSEN, L. \& VITTERSø, J. 2013. Personality and technology acceptance: The influence of personality factors on the core constructs of the Technology Acceptance Model. Behaviour \& Information Technology, 32 (4), 323-334.

SYKES, T. A., VENKATESH, V. \& RAI, A. 2011. Explaining physicians' use of EMR systems and performance in the shakedown phase. Journal of the American Medical Informatics Association, 18 (2), 125-130.

TAPIA, A. H., KVASNY, L. \& ORTIZ, J. A. 2011. A critical discourse analysis of three US 
municipal wireless network initiatives for enhancing social inclusion. Telematics and Informatics, 28 (3), 215-226.

TAY, L. \& DIENER, E. 2011. Needs and subjective well-being around the world. Journal of Personality and Social Psychology, 101 (2), 354.

TAYLOR, S. \& TODD, P. A. 1995. Understanding information technology usage: A test of competing models. Information Systems Research, 6 (2), 144-176.

TERZIS, V., MORIDIS, C. N. \& ECONOMIDES, A. A. 2012. How student's personality traits affect Computer Based Assessment Acceptance: Integrating BFI with CBAAM. Computers in Human Behavior, 28 (5), 1985-1996.

THE CHARITY COMMISSION 2001. The promotion of social inclusion. In: COMMISSION, T. C. (ed.).) UK: Crown.

TOKUNAGA, R. S. 2017. A meta-analysis of the relationships between psychosocial problems and internet habits: Synthesizing internet addiction, problematic internet use, and deficient self-regulation research. Communication Monographs, 1-24.

TUREL, O., SERENKO, A. \& BONTIS, N. 2007. User acceptance of wireless short messaging services: Deconstructing perceived value. Information \& Management, 44 (1), 63-73.

VALLACHER, R. R. \& KAUFMAN, J. 1996. Dynamics of action identification: Volatility and structure in the mental representation of behavior. In: GOLLWITZER, P. M. \& BARGH, J. A. (eds.) The psychology of action: Linking cognition and motivation to behavior. New York: Guilford.

VAN DEN BROECK, A., VANSTEENKISTE, M., DE WITTE, H., SOENENS, B. \& LENS, W. 2010. Capturing autonomy, competence, and relatedness at work: Construction and initial validation of the Work- related Basic Need Satisfaction scale. Journal of Occupational and Organizational Psychology, 83 (4), 981-1002.

VENKATESH, V. 2000. Determinants of perceived ease of use: Integrating control, intrinsic motivation, and emotion into the Technology Acceptance Model. Information Systems Research, 11 (4), 342-367.

VENKATESH, V. \& BALA, H. 2008. Technology Acceptance Model 3 and a research agenda on interventions. Decision Sciences, 39 (2), 273-315.

VENKATESH, V. \& DAVIS, F. D. 2000. A theoretical extension of the Technology Acceptance Model: Four longitudinal field studies. Management Science, 46 (2), 186204.

VENKATESH, V., DAVIS, F. D. \& MORRIS, M. G. 2007. Dead or alive? The development, trajectory and future of technology adoption research. Journal of the Association for Information Systems, 8 (4), 267.

VENKATESH, V., L. THONG, J. Y. \& XU, X. 2012a. Consumer acceptance and use of information technology: Extending the unified theory of acceptance and use of technology. MIS Quarterly, 36 (1), 157-178.

VENKATESH, V. \& MORRIS, M. G. 2000. Why don't men ever stop to ask for directions? Gender, social influence, and their role in technology acceptance and usage behavior. MIS Quarterly, 115-139.

VENKATESH, V., MORRIS, M. G., DAVIS, G. B. \& DAVIS, F. D. 2003. User acceptance of information technology: Toward a unified view. MIS Quarterly, 27 (3), 425-478.

VENKATESH, V., SYKES, T. A. \& VENKATRAMAN, S. 2012b. Understanding eGovernment portal use in rural India: Role of demographic and personality characteristics. Information Systems Journal, 24 (3), 249-269. 
WANG, C. 2014. Antecedents and consequences of perceived value in Mobile Government continuance use: An empirical research in China. Computers in Human Behavior, 34, $140-147$.

WEBB, T. L., JOSEPH, J., YARDLEY, L. \& MICHIE, S. 2010. Using the internet to promote health behavior change: A systematic review and meta-analysis of the impact of theoretical basis, use of behavior change techniques, and mode of delivery on efficacy. Journal of Medical Internet Research, 12 (1).

WONG, T. Y., YUEN, K. S. \& LI, W. O. 2014. A basic need theory approach to problematic Internet use and the mediating effect of psychological distress. Frontiers in Psychology, 5.

WU, W.-Y. \& KE, C.-C. 2015. An online shopping behavior model integrating personality traits, perceived risk, and technology acceptance. Social Behavior and Personality: an International Journal, 43 (1), 85-97.

YU, J., LEE, H., HA, I. \& ZO, H. 2015. User acceptance of media tablets: An empirical examination of perceived value. Telematics and Informatics. 